NBER WORKING PAPER SERIES

\title{
CORPORATE FOREIGN BOND ISSUANCE AND INTERFIRM LOANS IN CHINA
}

\author{
Yi Huang \\ Ugo Panizza \\ Richard Portes \\ Working Paper 24513 \\ http://www.nber.org/papers/w24513
NATIONAL BUREAU OF ECONOMIC RESEARCH
1050 Massachusetts Avenue
Cambridge, MA 02138
April 2018

We thank Valentina Bruno, Elias Papaioannou, Hyun Shin and Hélène Rey for their invaluable suggestions. We are grateful to Laura Alfaro, Chong-En Bai, Yan Bai, Fernando Broner, Anusha Chari, Michael Chui, Stijn Claessens, Zhiguo He, Haizhou Huang, Brandon Julio, Olivier Jeanne, Keyu Jin, Qian Jun, Chen Lin, Shu Lin, Xuewen Liu, Hans Genberg, Linda Goldberg, Robert McCauley, Maury Obstfeld, Eswar Prasad, Tao Shen, Alexander Swoboda, Cedric Tille, ShangJin Wei, Jenny $\mathrm{Xu}$, Yongding Yu, Vivian Yue and Hao Zhou for their comments. We also thank seminar participants at the Bank of England, Chinese Academy of Social Sciences, CEPR International Conference on Capital Flows and Safe Assets, China Institute of Finance and Capital Markets, Columbia-Tsinghua Conference in International Economics, China Securities Regulatory Commission (CSRC), European University Institute, Geneva Graduate Institute, Hong Kong Monetary Authority (HKMA), International Monetary Fund (IMF), London Business School, LSE-Tsinghua Workshop on Liberalization and Financial Resilience in Incomplete Markets, Peking University, State Administration of Foreign Exchange of China, Tsinghua University and Swiss National Bank. We thank Piao Shi for the data support and Yue Zhou for outstanding research assistance. The usual caveats apply. Corresponding author: rportes@london.edu. The views expressed herein are those of the authors and do not necessarily reflect the views of the National Bureau of Economic Research.

NBER working papers are circulated for discussion and comment purposes. They have not been peer-reviewed or been subject to the review by the NBER Board of Directors that accompanies official NBER publications.

(C) 2018 by Yi Huang, Ugo Panizza, and Richard Portes. All rights reserved. Short sections of text, not to exceed two paragraphs, may be quoted without explicit permission provided that full credit, including $(\subset$ notice, is given to the source. 
Corporate Foreign Bond Issuance and Interfirm Loans in China

Yi Huang, Ugo Panizza, and Richard Portes

NBER Working Paper No. 24513

April 2018

JEL No. F32,F34,G15,G30

\begin{abstract}
$\underline{\text { ABSTRACT }}$
This paper uses firm-level data to document and analyze international bond issuance by Chinese non-financial corporations and the use of the proceeds of issuance. We find that dollar issuance is positively correlated with the differential between domestic and foreign interest rates. This interest rate differential increases the likelihood of dollar bond issuance by risky firms and decreases the likelihood of dollar bond issuance of exporters and profitable firms. Moreover, and most strikingly, we find that risky firms do more inter-firm lending than non-risky firms and that this lending rose significantly after the regulatory shock of 2008-09, when the authorities sought to restrict the financial activities of risky firms. Risky firms try to boost profitability by engaging in speculative activities that mimic the behavior of financial institutions while escaping prudential regulation that limits risk-taking by financial firms.
\end{abstract}

Yi Huang

The Graduate Institute, Geneva

Maison de la paix

Chemin Eugène-Rigot 2

1202 Geneva, Switzerland

yi.huang@graduateinstitute.ch

Ugo Panizza

The Graduate Institute, Geneva

Department of International Economics

PO Box 36, 1211 Geneva 21

Switzerland

ugo.panizza@graduateinstitute.ch
Richard Portes

London Business School

Regent's Park

London NW1 4SA

UNITED KINGDOM

and NBER

rportes@london.edu 
The aftermath of the Global Financial Crisis was associated with a surge in foreign borrowing by emerging market nationals. Over 2007-2016, outstanding international bonds issued by nationals of developing countries increased from \$1.1 trillion to over \$3.1 trillion. Annual gross issuances, which stood at about $\$ 285$ billion in 2007, surpassed $\$ 820$ billion in 2016. Nonfinancial corporations played a key role in this surge in international bond issuances. ${ }^{1}$ There are concerns that when advanced economies start increasing interest rates, foreign currency debt could become a threat to financial stability in emerging market (EM) countries (Acharya et al., 2015, IMF, 2015, Alfaro et al., 2017).

China was a key player in this recent increase in bond issuance. International Bonds issued by Chinese nationals represented 3.5 percent of total outstanding international bonds issued by EM nationals in 2007 and are now more than 20 percent of the total (the dollar amount of outstanding bonds went from $\$ 20$ billion in 2007 to $\$ 823$ billion at the end of 2016). In 2007, total issuances of international bonds by Chinese nationals were 5 percent of total issuances by EM nationals, while in 2016 total issuances of international bonds by Chinese nationals were close to 40 percent of total issuances (the dollar value went from $\$ 3$ billion to $\$ 237$ billion). Outstanding international bonds issued by Chinese non-financial corporations increased from $\$ 9$ billion in 2007 (3\% of total outstanding international bonds issued by EM nationals' non-financial corporations) to $\$ 534$ billion in 2016 (65\% of total outstanding international bonds issued by EM nationals' non-financial corporations). The share of these bonds denominated in US dollars increased from 66 percent in 2007 to 85 percent in 2016.

This paper uses bond-level and firm-level data to document the main patterns of international bond issuances by Chinese non-financial corporations. We find that the pattern of borrowing and the use of borrowed funds differed considerably between safe firms on the

\footnotetext{
${ }^{1}$ The stock of outstanding international bonds issued by non-financial corporations increased from $\$ 355$ billion (32\% of total outstanding bonds) to $\$ 1.25$ trillion in 2016 (40\% of the total). The large majority of these bonds are denominated in US dollars, and the share of dollar-denominated bonds has increased from 79\% (90 percent if we also include bonds denominated in euro) in 2007 to $83 \%$ (92\% including bonds denominated in euro) in 2016.
} 
one hand, and risky firms on the other. In particular, the latter engaged in carry trade borrowing: acting like financial institutions. This is a form of "shadow banking" which has so far escaped attention in the study of Chinese financial intermediation. We start by analyzing the drivers of bond issuance and then describe how bond issuers use the proceeds. We show that, as expected, dollar bond issuances are positively correlated with firm size and leverage. We also find that there is no correlation between firm profitability and the likelihood to issue dollar bonds. Firms that belong to risky economic sectors, however, are more likely to issue dollar bonds. Surprisingly, we find that exporters (i.e., firms that have a natural hedge against currency fluctuations) are less likely to issue dollar-denominated bonds. Dollar issuances are positively correlated with the differential between domestic and foreign interest rates. This interest rate differential increases the likelihood of dollar bond issuances by risky firms and decreases the likelihood of dollar bond issuances by exporters and profitable firms. Our findings are not in line with the hypothesis that firms choose their liability structure to minimize jointly funding cost and currency risk. Hence, we conjecture that firms with limited profit opportunities borrow abroad to generate financial profits through carry trade activities.

When we explore how firms use the proceeds from dollar bond issuances, we find that issuers of dollar bonds have lower investment rates, hold more cash, and are more likely to lend to other firms. Next, we compare the behavior of safe firms with that of risky firms and find that the correlation between dollar bond issuances and inter-firm lending holds only for the latter group (see also, He et al., 2017, Jiang et al. 2010). These findings are consistent with the hypothesis that safe and profitable firms with good investment projects do not borrow much abroad. When they do so, they use the proceeds to finance investment projects. Riskier firms, instead, try to boost profitability by engaging in speculative activities that mimic the behavior of financial institutions while escaping prudential regulation that limits risk-taking by highly-leveraged financial firms. This is a form of 'shadow banking'. We conclude by showing that the surge in dollar borrowing by risky non-financial corporations could have resulted from regulatory decisions which intended to limit their risk-taking by limiting their access to domestic funds. Instead, it drove them to borrow abroad.

The paper is related to several strands of the literature spanning financial depth and corporate financial structure, the credit cycle, and systemic macroeconomic financial risks. As Shin and Zhao (2013), we build on the corporate finance literature suggesting that firms 
normally use internal sources to finance projects or operations and seek outside funds only after internal funds are exhausted (Myers 2004). This "pecking order" implies that in nonfinancial corporations, liabilities and liquid financial assets should be negatively correlated. This is the opposite of what happens for financial intermediaries that borrow to lend. One important paper in this line of research is Bruno and Shin (2016). These authors study the determinants of foreign bond issuances and find that they are driven by carry trade activities in emerging market countries but not in advanced economies. Caballero, Panizza, and Powell (2015) show that this result is driven by the presence of capital controls which give lightly regulated non-financial corporations a comparative advantage in moving funds across borders (see also Shin, 2013 and McCauley, Upper, and Villar, 2013). In the Chinese context, using bond issuance from the SDC database and firm-level data from Worldscope, Frank and Shen (2016) study the relationship between dollar bond issues and Chinese firms' leverage and investment decisions between 2000-2015. Their results show little evidence, however, of the carry trade activities we see elsewhere.

The paper also relates to the literature on incomplete financial markets. Large EM-based financial corporations have better access to capital markets than smaller firms with which they have relationships. These large corporations may act as bankers for smaller firms by using the informational advantage that come from their business relationships. Because of the characteristics of the Chinese financial system, our paper is also related to the literature on the links between international bond issuances and capital controls (Shin, 2013; McCauley, Upper, and Villar, 2013; Caballero, Panizza, and Powell, 2015; and Acharya and Vij, 2017).

Finally, our work is related to the growing literature on the development of Chinese capital markets and on the unintended consequences of the Chinese fiscal stimulus (Bai, Hsieh, and Song, 2016; Huang, Pagano, and Panizza, 2016; Cong and Ponticelli, 2016; Allen, Qian, Tu, and Yu, 2015; Acharya, Qian, and Yang, 2016; Brunnermeier and Wei, 2016; Chen, He and Liu, 2016; and Gao, Ru, and Tang, 2016).

The rest of the paper is organized as follows: Section 2 describes our data; Section 3 studies the drivers of bond issuance; Section 4 describes the use of the proceeds; Section 5 explores firm heterogeneity; Section 6 studies the relationship between inter-firm loans and a set of prudential policies that tightened access to domestic credit for firms that operate in risky sectors; Section 7 concludes. 
From a global perspective, there was overwhelming dollar liquidity after the 2008 financial crisis, as suggested by the low borrowing cost on dollars. The Chinese government bond yield surpassed the US Treasury bill yield in 2008 for the first time in the $21^{\text {st }}$ century. ${ }^{2}$ The government bond interest rate then transmitted to the corporate bond market, where the corporate bond yield spread between US and China converged dramatically by almost 5 percentage points.

China reacted to the global financial crisis with a massive fiscal stimulus. In November 2008, the government announced a package worth 4 trillion Yuan (approximately USD 590 billion). The plan was implemented immediately. Most of the funds were channeled through local governments and funded with bank loans (Bai et al., 2016, estimate that about 90 percent of local government investment was financed with bank loans in 2009). This policy action tightened the credit conditions faced by private firms (Huang, Pagano, and Panizza, 2016) and led to a rise in the shadow lending rate (Wenzhou rate) faced by Chinese firms, which increased from approximately 13 percent in the winter of 2009-2010 to nearly 21 percent in mid-2011 (Figure 1). The shadow rate decreased again in late 2011, but at 15 percent in 2016 it remained well above its pre-global financial crisis level of 10-11 percent. The regulated official lending rate, instead, did not change.

This period was also characterized by a set of regulatory reforms that tightened access to credit for firms that belong to economic sectors deemed to be "risky" or characterized by excess capacity. In a classic case of regulatory arbitrage, these policies contributed to the rapid growth of the Chinese shadow banking system (Chen, Ren, and Zha, 2016) and to the spike in the shadow lending rate documented above.

The increase in the shadow lending rate was soon followed by a sudden jump in the issuance of international foreign currency denominated bonds by Chinese non-financial firms. The stock of outstanding bonds increased from $\$ 49$ billion in early 2011 to $\$ 86$ billion at the end of 2012 and exceeded \$534 billion in 2016Q4. Approximately 90\% of these bonds are denominated in US dollars, see Figure 1.

\footnotetext{
${ }^{2}$ See Figure A1 in the Appendix.
} 
But the official data seem to underestimate the growth of foreign currency debt. ${ }^{3}$ In this paper, we go beyond aggregate data and conduct a detailed analysis of the drivers of bond issuance by Chinese non-financial corporations. We shall see that firms that issue dollar bonds are more likely to become lenders in the shadow banking system.

\subsection{Data}

We study the drivers and consequences of dollar bond issuance by merging bond-level data from Dealogic with firm-level data from China Stock Market and Accounting Research (CSMAR).

As a first step, we collect information on all bonds issued by Chinese nationals over the period 2005-15. The focus on nationals rather than residents is important because over 200915 there was a massive increase in international bond issuance by non-resident Chinese nationals (see Figure 2A, and also Shin, 2013, and McCauley, Upper, and Villar, 2013). Our bond-level data contain 25,123 observations and include domestic and international issuances in all currencies by all types of issuers. Dealogic data for international issuance by Chinese nationals match the aggregate data published by the Bank for International Settlements (Figure 2B).

Total bond issuances (domestic and international) increased from $\$ 425$ billion in 2008 to about $\$ 1$ trillion in 2010 and then reached $\$ 1.5$ trillion in 2016. As we focus on non-financial sector listed firms, we exclude from our dataset all bonds issued by financial institutions and the central government (8,394 bonds) and all bonds issued by non-listed corporations $(12,008$ bonds). Finally, we also drop from the sample a small number of bonds (176 in total) which are issued in currencies different from the US dollar or the RMB. ${ }^{4}$ Our final sample consists of

\footnotetext{
${ }^{3}$ We compared our foreign currency bond outstanding from Dealogic with that of BIS and the official foreign currency debt. State Administration of Foreign Exchange (SAFE) discloses the exposure to foreign currency debt until 2014. Later, the definition has been changed to foreign claims on China which is a broader concept. The comparison shows that the growth rate of foreign currency debt from Dealogic follows the BIS data trend, but outpaced the official foreign currency debt growth (see Figure A2 in the Appendix). Given that the foreign currency loans were also growing, our data imply that the official data might underestimate the level and the growth of the foreign currency debt.

${ }^{4}$ We do this because we mostly focus on US dollar issuances. All our results are robust to keeping these 176 bonds issued in other currencies in the sample.
} 
4,454 bonds from 1,353 issuers. About 85 percent of these bonds are denominated in RMB and the remaining 15 percent (557 bonds and 238 issuers) are denominated in US dollars.

Our data show that bond issuance by Chinese non-financial corporations remained well below $\$ 200$ billion until 2010 and then started increasing rapidly in 2012 and surpassed $\$ 900$ billion in 2016 (Figure 3). Dollar issuance also increased rapidly from $\$ 9$ billion in 2008 to over $\$ 230$ billion in 2016. The total number of bonds issued by non-financial corporations increased from 100 in 2007 (9 of these bonds were denominated in US dollars) to 4,110 in 2016 (165 of these bonds were denominated in US dollars).

Next, we collect firm-level information from CSMAR. We start with a total of nearly 60,000 observations and after restricting our sample to listed non-financial and nongovernment sectors with complete data on revenues and inter-firm loans, we are left with approximately 32,815 observations covering 2,593 firms.

Finally, we manually match the bond-level and the firm-level data. We are able to recover information for most bond issuers, but there are 486 bonds (of which 78 are dollardenominated bonds) for which we cannot find issuer data. Therefore, our final sample consists of 4,472 bonds (567 of these bonds are denominated in US dollars). About one-third of the firms in our sample have issued at least one bond, and 6 percent of the firms in our sample have issued dollar-denominated bonds.

The data summary is shown in the appendix Table A1.

\section{Determinants of dollar bond issuance}

We describe what types of firms issue international dollar-denominated bonds with a simple set of linear probability models. ${ }^{5}$ We use OLS to regress a dummy that takes a value of one if firm $i$ issues a bond in year $t$ over a set of firm characteristics, two proxies for carry trade opportunities, and the interaction between firm characteristics and carry trade opportunities. Some of our regressions also include year and firm-fixed effects. ${ }^{6}$

The set of firm characteristics includes profitability (proxied by return on assets, ROA), firm size (proxied by the log of total assets), leverage (total debt over assets), foreign exposure

\footnotetext{
${ }^{5}$ Probit or logit estimates yield similar results.

${ }^{6}$ In all regressions, we winsorize the data at $2 \%$.
} 
(proxied by exports over revenues), and a dummy variable that takes a value of one for firms that belong to sectors that China's Ministry of Industry and Information Technology has defined as "risky". ${ }^{7}$ The proxies for carry trade opportunities are the Bloomberg Carry Trade Performance Index (this index measures the 3-month return of borrowing in USD and investing in $\mathrm{RMB}$ ) and the Wenzhou index of private lending interest rates in the Chinese shadow banking system.

We start by regressing the issuer dummy over firm characteristics and a set of year fixed effects (Table 1, column 1) ${ }^{8}$. Profitability is not correlated with the likelihood of issuing dollar bonds. But leverage and firm size are positively correlated with the likelihood of issuing dollar bonds (Bruno and Shin, 2016, find similar results for their sample of emerging market countries, although in their regressions leverage is positive but not statistically significant). This is not surprising. Leveraged firms are more likely to seek different types of financial resources, and large firms can cover the fixed costs linked to issuing abroad. What is surprising is that firms with high foreign exposure (i.e., firms that have a natural hedge when they borrow in foreign currency) are less likely to issue dollar bonds, and firms in risky sectors (which often produce non-tradable goods) are more likely to issue dollar bonds. We return later to the second observation and its consequences.

Figure 4 plots the year fixed effects recovered from the regression of Column 1, Table 1 and shows that the trend in dollar bond issuances documented in the previous section is robust to controlling for firm characteristics. Moreover, the year fixed effects comove with the Bloomberg carry trade performance index and with the Wenzhou shadow interest rate. This correlation is also confirmed by columns 2 and 3 of Table 1 which replace the year fixed effects with these two proxies of carry trade opportunities and show that the potential for carry trade returns is positively correlated with dollar bond issuances.

The observed correlation between carry trade returns and dollar bond issuances could be spurious, driven by the fact the Chinese financial system began its slow internationalization process in a period of low and decreasing dollar interest rates.

\footnotetext{
${ }^{7}$ Risky sectors include real estate and other sectors which, according to China's Ministry of Industry and Information Technology (CMIIT), are characterized by excessive capacity. We manually code the various sectors as risky using CMIIT's definition. Appendix A provides a full list of sectors classified as risky.

${ }^{8}$ In the online appendix, we show that our results are robust to using a panel logit model (Table A2).
} 
Alternatively, in the presence of deviations from uncovered interest parity, the large and growing difference between RMB and dollar rates could be the driver of dollar bond issuances. We explore these two explanations by interacting the demeaned carry trade (column 4) and shadow rate (column 5) indexes with firm characteristics. Formally, we estimate the following model:

$$
\operatorname{ISSUER}_{i, t}=X_{i, t-1} \Gamma+\widetilde{c t}_{t}^{\prime} X_{i, t-1} \Psi+\delta \widetilde{c t}_{t}+\varepsilon_{i, t}
$$

ISSUER is a dummy variable that takes value one if firm $i$ issues a dollar bond in year $\mathrm{t}, X_{i, t-1}$ is a matrix of firm characteristics, and $\widetilde{c t}_{t}$ is the demeaned carry trade (or shadow rate) index. ${ }^{9}$ We remove the mean from the index so that the coefficients of the non-interacted variables (the matrix $\Gamma$ ) measure the effect of firm characteristics when carry trade opportunities are at their mean value, and the coefficients of the interacted variables (the matrix $\Psi$ ) measure how changes in carry trade opportunities affect the relationship between firm characteristics and the likelihood of issuing dollar bonds. Note that we do not remove the mean from the matrix of firm characteristics. Hence, $\delta$ has no natural interpretation, as it measures the effect of the carry trade index when $X=0$. We also estimate versions of (1) which include firm and year fixed effects. With year fixed effects, we cannot estimate the parameter $\delta$. But the fixed effects regressions estimate the within-firm and within-year relationship of the interactions between firm characteristics and the two measures of carry trade opportunities. Hence they are free of the spurious correlation problem mentioned above.

In columns 4 and 5 of Table 1, the coefficients of the non-interacted variables are close to those of columns 2 and 3 . The main effects of the shadow rate and the carry trade return index are negative. As mentioned above, however, these coefficients have no natural interpretation because they measure the correlation between potential carry trade returns and dollar bond issuances when all other control variables are set equal to zero.

In the presence of large return differentials, dollar issuances can substantially reduce funding costs. This is a risky strategy, however, because a sudden dollar appreciation may lead to large losses through negative balance sheet effects. Exporters have a natural hedge

\footnotetext{
${ }^{9} \mathrm{We}$ define $\widetilde{c t} t_{t}=c t_{t}-\overline{c t}$, where $c t_{t}$ is the carry trade index in year $\mathrm{t}$ and $\overline{c t}$ is the average value of the carry trade index.
} 
against currency depreciation and, other things equal, are in a better position to exploit return differentials by issuing dollar bonds. The same applies to large and profitable firms which have a greater capacity to absorb losses brought about by negative balance sheet effects. The opposite should instead be true for more fragile firms that are either highly leveraged or belong to risky sectors.

Our results do not support these priors. While we find that interest rate differentials increase the likelihood that large firms issue dollar bonds, the results for other firm characteristics are the opposite of what prudent debt management would suggest. We find that profitable firms and exporters are less likely to issue dollar bonds when carry trade returns are high, while leveraged and risky firms are more likely to issue dollar bonds in the presence of high carry trade returns. The last two columns of Table 1 show that these results for the interacted variables are robust to controlling for firm and year fixed effects. ${ }^{10}$

These results suggest that firms may not choose their liability structure to minimize jointly funding cost and exchange rate risk. Instead, firms with limited investment opportunities may borrow abroad not to finance investment projects, but to generate financial profits through carry trade activities. Alternatively, risky firms may borrow abroad to evade regulations that prevent them from tapping the domestic financial market. We now examine their uses of funds.

\section{$4 \quad$ Use of proceeds}

We now check what issuers do with the proceeds of dollar bond issuances. Financial frictions make external funds more expensive than internal funds and generate a "pecking order" for firm financing. Non-financial firms normally use internal sources to finance projects or operations and seek outside funds only when those are exhausted (Myers 2004). Banks borrow to lend, and their balance sheets show a positive correlation between financial assets (mostly loans) and financial liabilities (deposits or other forms of debt for non-deposit taking financial institutions). Instead, non-financial corporations borrow to invest (or to finance current

\footnotetext{
${ }^{10}$ The only difference is that the main effect of ROA in column 7 becomes positive and statistically significant.
} 
expenditure), and their debt liabilities should be negatively correlated with their liquid financial assets (Shin and Zhao 2013).

As bonded debt tends to have longer maturity than the typical bank overdraft (the average maturity in our sample of dollar denominated bonds is 7 years), dollar bond issuances should be positively correlated with fixed investment. We test this hypothesis by estimating the following model:

$$
\frac{\text { CAPEX }_{i, t}}{A_{i, t-1}}=\beta \text { ISSUER }_{i, t-1}+X_{i, t-1} \Gamma+\alpha_{i}+\tau_{t}+\varepsilon_{i, t}
$$

where the dependent variable is investment in fixed assets over lagged total assets, ISSUER measures bond issuances in the previous year, $X$ is a matrix of firm characteristics (profitability, proxied by ROA, leverage, and size), and $\alpha_{i}$ and $\tau_{t}$ are firm and year fixed effects.

We use three definitions of ISSUER: (i) a dummy variable that takes value one if the firm has issued in a given year (columns 1 and 2 of Table 2); (ii) bond issuances over revenues (columns 3 and 4); and (iii) outstanding bonds over revenues (column 5 and 6). Columns 1, 3, and 5 of Table 2 show that there is often a negative (the exception is column 1) but not statistically significant correlation between dollar bond issuance and investment in fixed assets.

Columns 2, 4, and 6 interact bond issuance with the carry trade index (as before, we remove the mean from the index). We find that the correlation between bond issuance and capital expenditure tends to be higher when there is a large differential between domestic and foreign interest rates. However, the coefficient is statistically significant only in one of the three regressions. We also conduct robustness check by scaling the variables with total assets (Table A3).

On average, listed Chinese non-financial firms do not issue dollar bonds to invest in fixed assets. Shin and Zhao (2013) and Bruno and Shin (2016) have argued that EM-based nonfinancial corporations often act like financial intermediaries and, instead of borrowing to invest, they borrow to lend. We test their hypothesis by regressing cash-in-hand (a measure of liquid financial assets) divided by lagged revenues over the same set of controls as in 
Equation (1). ${ }^{11}$ Table 3 corroborates Shin and Zhao's (2013) result. USD bond issuers tend to hold more cash than non-issuers (columns 1, 3, and 5). The table also shows that the correlation between USD bond issuances and cash holdings becomes stronger when there is a large difference between domestic and dollar interest rates (columns 2, 4, and 6). The coefficients, however, are not always statistically significant. Results are robust if we scale the variables with total assets (Table A4).

It is not surprising that, in the Chinese context, the correlation between dollar bond issuances and cash holdings is not always statistically significant. Such a correlation would be strong if Chinese non-financial corporations tried to earn carry trade returns by borrowing in US dollars and depositing the money in the domestic financial system. This strategy is unlikely to maximize carry trade profit, however, because Chinese deposit rates are capped well below the market rate. A non-financial corporation that wants to maximize carry trade returns is more likely to lend to other firms, either directly or through entrusted loans (Allen, Qian, $\mathrm{Tu}$, and $\mathrm{Yu}, 2016)$. Therefore, we replace cash-at-hand with inter-firm loans. ${ }^{12}$ Table 4 shows that there is a positive and statistically significant correlation between dollar bond issuances and inter-firm loans (columns 1, 3 and 5). This correlation becomes particularly strong when there is a large differential between dollar and RMB rates (columns 2, 4, and 6). If we augment the models of Table 4 with issuances of bonds denominated in RMB, we find that only dollar bonds are robustly correlated with inter-firm loans (the correlation for RMB bond issuances is statistically significant in one of our six regressions). The interaction between bond issuances and carry trade returns is statistically significant only for dollar bond issuances (Table 5).

The regressions of columns 1 and 2 of Table 6 focus on the extensive margin (i.e., they differentiate between firms that issue and do not issue bonds). The regressions of columns 36 , instead, mix the intensive and the extensive margins. Specifically, they assume that a given bond issuance has the same effect for firms that are issuing for the first time and for firms that were already issuing before. When we separate the two effects by jointly controlling for an issuer dummy and for the total amount issued in a given year (columns 1 and 2 of Table 6 ) or total outstanding amount (columns 3 and 4 of Table 6), we find that it is the intensive margin

\footnotetext{
${ }^{11}$ This is the same specification used by Shin and Zhao (2013).

12 We use "other receivables" over revenues.
} 
that matters. Firms that issue more dollar bonds or have a larger stock of outstanding dollar bonds tend to lend more to other firms. If we estimate the same models of Table 6 using capital expenditure as the dependent variable, we find that there is no statistically significant correlation between dollar bond issuances (extensive and intensive margin) and capital expenditure. Also, the interaction between the carry trade index and dollar bond issuances (both margins) is not statistically significant. ${ }^{13}$

On the other hand, domestic credit conditions also affect inter-firm loans. If the domestic unsecured interest rate is sufficiently higher than that in the international market, firms with access to the dollar bond market would invest the offshore money in the domestic market to earn a higher expected return. Table 7 shows how the dollar bond issuers take advantage of the domestic shadow rate to conduct inter-firm loans. We augment the interaction term between shadow rate and USD issuer indicators in column 1-3. The coefficients of the interaction terms are significantly positive, suggesting that a higher domestic shadow rate triggers the USD issuers to conduct more inter-firm loans. Columns 46 replace the shadow rate with a dummy variable that equals 1 if the shadow rate is above the median and 0 if below. The results are robust for all the three measurements of USD issuer.

In the literature, it is also common to standardize inter-firm loans with total assets. Table 8 reports similar results when the variables are scaled by total assets. Dollar bond issuers usually have more inter-firm loans than non-issuers, and the sensitivity of inter-firm loan to dollar bond issuances is stronger when the carry trade index is higher. Results for the control variables are the same as in the baseline regression.

We also estimate the same models of Table 5 by scaling the inter-firm loans and dollar bond issuances/outstanding with total assets. Table 9 reports the results, which are similar to those of Table 5.

\section{$5 \quad$ Firm heterogeneity}

In section 3, we showed that riskier and less profitable firms are more likely to issue dollar bonds when there are large potential returns from carry trade activities. The results in Table 10, which show that dollar bond issuances are negatively correlated with capital expenditure

\footnotetext{
${ }^{13}$ Full regression results available upon request.
} 
and positively correlated with cash holdings and inter-firm loans, are also consistent with the presence of carry trade activities.

We now check whether the correlation between dollar bond issuances and interfirm loans (our 'smoking gun' for carry trade activities) is stronger for riskier and less profitable firms. We start by estimating the baseline model of Table 6 (column 1) augmented with the interaction between the two issuer variables (intensive and extensive margin) and firm profitability proxied by returns on assets. As before, we find that inter-firms loans are positively correlated with bond issuance (Table 10, column 1). We also find, however, that the interaction term is negative and statistically significant, indicating that profitable firms that issue dollar bonds are less likely to engage in inter-firm lending activities.

Next, we interact dollar issuances with the risky sector dummy described above (column 2). For firms that do not belong to risky sectors, there is a negative correlation between dollar bond issuances and inter-firm loans, while the correlation is instead positive and statistically significant for firms that belong to risky sectors. The effect is also economically significant, as it suggests that risky firms lend more than $37 \%$ of US dollar bond proceedings to other firms.

Finally, we interact dollar bond issuance with Tobin's Q (column 3) and, as in the case of profitability, we find that firms with high market-to-book value are less likely to onlend the proceedings of US dollar issuances.

The last three columns of Table 10 show that the results are robust to using outstanding dollar bonds instead of dollar bond issuances.

The results of Tables 1-10 can be summarized as follows: (i) Riskier firms are more likely to issue dollar bonds, and they are more likely to do so when returns to carry trade are high; (ii) on average, firms that issue dollar bonds are less likely to invest in fixed capital and are more likely to lend to other firms; (iii) when we separate between safe and profitable firms and risky firms with low profitability, we find that the correlation between dollar bond issuance and inter-firm lending holds only for the latter group.

These findings paint a consistent picture in which safe and profitable firms with good investment projects do not borrow much abroad, and when they do so they use the funds to finance investment projects. Riskier firms, instead, try to boost profitability by engaging in speculative activities that mimic the behavior of financial institutions. They operate in the 
shadow banking system, escaping the various types of prudential regulation that limit risk taking by leveraged financial firms.

A natural reaction to this state of affairs is to propose regulating these firms, preventing them from taking too much risk. Regulation, however, is always complex. When it is not well implemented it can backfire. It is indeed possible that the rapid increase of dollar issuances by risky firms is the outcome of regulatory reforms aimed at limiting risk-taking by this type of firm.

The unintended consequences of prudential regulation: interfirm lending

Worried about increasing corporate financial vulnerability, on December 22, 2009 the People's Bank of China, the China Banking Regulatory Commission, the China Securities Regulatory Commission, and the China Insurance Regulatory Commission jointly released a document titled Guiding Opinions on Further Strengthening Financial Services With a View to Supporting the Adjustment and Rejuvenation of Some Key Industries and Restraining Excess Capacity in Other Industries (PBC Document No.386 [2009]). ${ }^{14}$ The document stated that "in order to serve the overall objective of supporting economic growth and restructuring the economy," the People's Bank of China will "enhance surveillance on credit structure," and "effectively contain overcapacity." This document tightened access to domestic credit (bank loans and issuance of securities) for firms that operate in economic sectors that are deemed to be risky (for a detailed classification see Table A5). On May 28, 2010, the People's Bank of China and the China Banking Regulatory Commission issued a joint regulation titled "Notice on Financial Services to Further Support Energy Saving and Eliminate the Backward-Production Capacity", which further restrained access to credit for firms that operate in risky sectors.

In a classic case of regulatory arbitrage, there is evidence that these policies contributed to the rapid growth of the Chinese shadow banking system. Chen, Ren, and Zha (2016) show that the share of entrusted loans (a typical shadow banking instrument in China) in total bank lending tripled during the tightening period, and more than 60 percent of these entrusted loans were channeled to firms that operate in risky sectors. In fact, we find that the risky

\footnotetext{
${ }^{14}$ http://www.pbc.gov.cn/english/130721/2872680/index.html
} 
sectors not only channel more inter-firm loans, but also provide less provision for their exposure, see Figures 5 and 6.

Here we study a different type of regulatory arbitrage. We use the policy shock of 200910 as a means of identification. Specifically, we test whether the regulatory reforms of 200910 increased the likelihood that risky firms issue dollar bonds and then use the proceeds to onlend to domestic firms in similar sectors. The rationale for such behavior is that information asymmetries are paramount in the shadow banking system, but these information asymmetries are likely to be less important for firms that operate in the same sector. Hence firms that lend through entrusted loans (or other shadow banking instruments) are more likely to fund firms that operate in similar sectors (or similar cities, for evidence see Allen, Qian, Tu, and $\mathrm{Yu}, 2016)$.

Table 2 depicts respectively dollar bond issuance (Panel A) and outstanding dollar bonds (Panel B) by risky sectors since 2006. The proportion of dollar bonds issued by risky sectors surged immediately after the 2009 regulations. From 2010-2012, dollar bonds issued by risky sectors account for nearly $20 \%$ of the total issuance, with the dollar bond outstanding from risky sectors growing to $18 \%$ of the total exposure.

Consider now a situation in which firms in risky sectors face tighter domestic credit conditions, while some large firms that belong to risky sectors are unconstrained as they have access to the international capital market. Then these large firms can exploit their knowledge of credit constrained firms that operate in similar sectors by borrowing abroad and then onlending to risky sector firms domestically. We test this hypothesis by estimating the following differences-in-differences model:

$$
\frac{\text { InterFirmLoans }_{i, t}}{\text { Revenues }_{i, t}}=\alpha \text { ISSUER }_{i, t}+\beta \text { POLICY }_{t}+\delta\left(\text { ISSUER }_{i, t} \times P O L I C Y_{t}\right)+\varepsilon_{i, t}
$$

Here ISSUER is a dummy variable that takes the value one for firms that issue dollar bonds and the value zero for firms that do not issue dollar bonds, and POLICY is a dummy variable that takes the value zero for the period 2006-2009 and the value one for the period 2010-2014. ${ }^{15}$

\footnotetext{
${ }^{15}$ We show that our results are robust to using 2008 as a break year.
} 
Our parameter of interest is $\delta$, which measures whether the policy had a differential effect for firms that issue dollar bonds.

Column 1 of Table 12 shows that $\delta$ is positive and statistically significant, indicating that the policy led to an increase in inter-firm loans by firms that issue dollar bonds but had no effect for firms that do not issue dollar bonds (in fact, the effect for non-issuers is negative, albeit small, and statistically significant).

As dollar issuers are more likely to belong to risky sectors (see Table 1), we check whether the policy had an effect on risky sector firms by substituting the ISSUER dummy with a dummy variable that takes the value one for firms that belong to risky sectors. Column 2 of Table 12 shows that firms in risky sectors have higher inter-firm loans than firms that do not belong to risky sectors ( $\alpha$ is positive and statistically significant) and that the policy shock increases inter-firm loans in risky sectors. Column 3 of Table 12 separates the effect of being in a risky sector and that of issuing dollar bonds and suggests that belonging to a risky sector is key for explaining inter-firm loans in the post-2008 period.

\section{$7 \quad$ Conclusions}

The aftermath of the global financial crisis was characterized by a massive increase in international bond issuances by emerging market nationals. Non-financial firms played an important role, and Chinese issuers now account for 20 percent of outstanding international bonds issued by EM nationals and 22 percent of international bond issuances by EM nonfinancial corporations.

This paper uses firm-level data to analyze the main patterns of international bond issuances by Chinese non-financial corporations. It shows that dollar bond issuance is positively correlated with firm size and leverage, but that there is no correlation between firm profitability and the likelihood to issue dollar bonds. Firms that belong to risky economic sectors are more likely to issue dollar bonds. Surprisingly, we find that exporters (i.e., firms that have a natural hedge against currency fluctuations) are less likely to issue dollardenominated bonds. We also find that dollar issuances are positively correlated with the differential between domestic and foreign interest rates. This interest rate differential 
increases the likelihood of dollar bond issuance by risky firms and decreases the likelihood of dollar bond issuance of exporters and profitable firms.

These results are not in line with the hypothesis that firms choose their liability structure to jointly minimize funding cost and currency risk. Our findings are instead consistent with a situation in which safe and profitable firms with good investment projects do not borrow much abroad, and when they do so, they use the funds to finance investment projects. Riskier firms, instead, try to boost profitability by engaging in speculative activities that mimic the behavior of financial institutions while escaping the various types of prudential regulation that limit risk taking in highly-leveraged financial firms. They engage in a specific form of carry trade executed in the framework of China's shadow banking system. 


\section{References}

Acharya, V. V., and Steffen, S. (2015). The "greatest" carry trade ever? Understanding eurozone bank risks. Journal of Financial Economics, 115(2), 215-236.

Acharya, V. V., \& Vij, S. (2016, December). Foreign Currency Borrowing of Corporations as Carry Trades: Evidence from India. In NSE-NYU Conference on Indian Financial Markets (pp. 21-22).

Alfaro, L., Asis, G., Chari, A., and Panizza, U. (2017). Lessons unlearned? Corporate debt in emerging markets: National Bureau of Economic Research.

Allen, F., Qian, Y., Tu, G., and Yu, F. (2016). Entrusted Loans: A Close Look at China's Shadow Banking System.

Bai, C.-E., Hsieh, C.-T., and Song, Z. M. (2016). The long shadow of a fiscal expansion: National Bureau of Economic Research.

Brunnermeier, M.K., Sockin, M., and Xiong, W., 2017. China's gradualistic economic approach and financial markets, American Economic Review PEP, 107 (5), 608-13.

Bruno, V., and Shin, H. S. (2013). Capital flows, cross-border banking and global liquidity: National Bureau of Economic Research.

Bruno, V., and Shin, H. S. 2015. Capital flows, cross-border banking and global liquidity. Lournal of Monetary Economics Volume 71, April 2015, Pages 119-132

Bruno, V., and Shin, H. S. (2017). Global dollar credit and carry trades: a firm-level analysis. The Review of Financial Studies, 30(3), 703-749.

Caballero, J., Panizza, U., and Powell, A. (2015). The second wave of global liquidity: Why are firms acting like financial intermediaries?

Chen, K., Ren, J., and Zha, T. (2016). What we learn from China's rising shadow banking: exploring the nexus of monetary tightening and banks' role in entrusted lending: National Bureau of Economic Research.

Cong, L. W., and Ponticelli, J. (2016). Credit allocation under economic stimulus: Evidence from China.

Elekdag, S., Alter, A., Arregui, N., Ichiue, H., Khadarina, O., Kikkawa, A.K., Kumarapathy, S., Narita, M., and Zhang, J., 2015. Corporate leverage in emerging markets I a concern, IMF Global Financial Stability Review. 
Gao, H., Ru, H., and Tang, D.Y., 2017. Subnational debt of China: The politics-governance nexus, Working paper.

Gruić, B., Upper, C., and Villar, A. (2014). What does the sectoral classification of offshore affiliates tell us about risks? BIS Quarterly Review, 20-21.

Frank, M. and Shen, T. (2016). U.S. Dollar Debt Issuance by Chinese Firms.

He, Q., Lu, L., \& Ongena, S. (2016). Who gains from credit granted between firms? Evidence from inter-corporate loan announcements made in China.

Huang, Y., Pagano, M., and Panizza, U. (2016). Public debt and private firm funding: Evidence from Chinese cities.

Jiang, G., Lee, C. M., \& Yue, H. (2010). Tunneling through intercorporate loans: The China experience. Journal of Financial Economics, 98(1), 1-20.

Mayer, C., and Sussman, O. (2004). A new test of capital structure.

Myers, S. C. (1984). Finance theory and financial strategy. Interfaces, 14(1), 126-137.

Shin, H. S. (2014). The second phase of global liquidity and its impact on emerging economies Volatile Capital Flows in Korea (pp. 247-257): Springer.

Shin, H. S., and Zhao, L. (2013). Firms as surrogate intermediaries: evidence from emerging economies. Asian Development Bank, December. 


\section{Table 1: The drivers of US dollar bond issuance}

This table contains a set of OLS firm-level regressions where the dependent variable is a dummy that takes value 1 in years when a firm issues a dollar bond and the controls are the lagged values of return on assets (ROA), leverage, firm size (measured as the log of total assets), share of exports over total revenues (For. Exp.) a dummy variable that takes value 1 for firms that belong to risk sectors, the Bloomberg carry trade index (CT) and the Wenzhou shadow rate index (SR). These two indexes are not lagged. Coefficients and standard errors are multiplied by 100 to improve readability.

\begin{tabular}{|c|c|c|c|c|c|c|c|}
\hline & (1) & (2) & (3) & (4) & (5) & (6) & (7) \\
\hline ROA & $\begin{array}{c}0.12 \\
(0.18)\end{array}$ & $\begin{array}{c}0.16 \\
(0.19)\end{array}$ & $\begin{array}{c}0.04 \\
(0.20)\end{array}$ & $\begin{array}{l}-0.24 \\
(0.19)\end{array}$ & $\begin{array}{l}-0.13 \\
(0.20)\end{array}$ & $\begin{array}{c}0.09 \\
(0.26)\end{array}$ & $\begin{array}{l}0.54^{*} \\
(0.28)\end{array}$ \\
\hline Leverage & $\begin{array}{c}2.63 * * * \\
(0.38)\end{array}$ & $\begin{array}{c}2.59 * * * \\
(0.38)\end{array}$ & $\begin{array}{c}2.49 * * * \\
(0.40)\end{array}$ & $\begin{array}{c}0.63 \\
(0.39)\end{array}$ & $\begin{array}{c}1.30 * * * \\
(0.41)\end{array}$ & $\begin{array}{c}0.17 \\
(0.47)\end{array}$ & $\begin{array}{l}1.20 * * \\
(0.51)\end{array}$ \\
\hline Ln(Asset) & $\begin{array}{c}0.76 * * * \\
(0.07)\end{array}$ & $\begin{array}{c}0.76 * * * \\
(0.07)\end{array}$ & $\begin{array}{c}0.91^{* * *} \\
(0.07)\end{array}$ & $\begin{array}{c}0.88^{* * *} \\
(0.07)\end{array}$ & $\begin{array}{c}0.96 * * * \\
(0.07)\end{array}$ & $\begin{array}{c}0.77 * * * \\
(0.13)\end{array}$ & $\begin{array}{c}0.68 * * * \\
(0.14)\end{array}$ \\
\hline For. Exp. & $\begin{array}{c}-0.85^{* * *} \\
(0.16)\end{array}$ & $\begin{array}{c}-0.84 * * * \\
(0.17)\end{array}$ & $\begin{array}{c}-0.82 * * * \\
(0.18)\end{array}$ & $\begin{array}{c}-0.62 * * * \\
(0.16)\end{array}$ & $\begin{array}{c}-0.74 * * * \\
(0.18)\end{array}$ & $\begin{array}{l}-0.11 \\
(0.23)\end{array}$ & $\begin{array}{l}-0.33 \\
(0.26)\end{array}$ \\
\hline Risky Sector & $\begin{array}{c}1.34 * * * \\
(0.25)\end{array}$ & $\begin{array}{c}1.35 * * * \\
(0.25)\end{array}$ & $\begin{array}{c}1.29 * * * \\
(0.27)\end{array}$ & $\begin{array}{c}1.32 * * * \\
(0.25)\end{array}$ & $\begin{array}{c}1.31 * * * \\
(0.26)\end{array}$ & & \\
\hline CT & & $\begin{array}{c}0.07 * * * \\
(0.01)\end{array}$ & & $\begin{array}{c}-2.25 * * * \\
(0.14)\end{array}$ & & & \\
\hline SR & & & $\begin{array}{c}0.09 * * * \\
(0.03)\end{array}$ & & $\begin{array}{c}-4.09 * * * \\
(0.38)\end{array}$ & & \\
\hline ROA*CT & & & & $\begin{array}{c}-0.06 * * * \\
(0.02)\end{array}$ & & $\begin{array}{c}-0.07 * * * \\
(0.02)\end{array}$ & \\
\hline Leverage*CT & & & & $\begin{array}{c}0.18^{* * *} \\
(0.04)\end{array}$ & & $\begin{array}{c}0.14^{* * *} \\
(0.05)\end{array}$ & \\
\hline Ln(Asset)*CT & & & & $\begin{array}{c}0.10^{* * *} \\
(0.01)\end{array}$ & & $\begin{array}{c}0.11 * * * \\
(0.01)\end{array}$ & \\
\hline Foreign & & & & $\begin{array}{c}-0.08 * * * \\
(0.02)\end{array}$ & & $\begin{array}{c}-0.08^{* * *} \\
(0.02)\end{array}$ & \\
\hline Risky*CT & & & & $\begin{array}{c}0.15^{* * *} \\
(0.02)\end{array}$ & & $\begin{array}{c}0.15^{* * *} \\
(0.02)\end{array}$ & \\
\hline $\mathrm{ROA} * \mathrm{SR}$ & & & & & $\begin{array}{l}-0.05 \\
(0.05)\end{array}$ & & $\begin{array}{l}-0.02 \\
(0.06)\end{array}$ \\
\hline Leverage*SR & & & & & $\begin{array}{c}0.06 \\
(0.13)\end{array}$ & & $\begin{array}{l}-0.04 \\
(0.13)\end{array}$ \\
\hline Ln(Asset)*SR & & & & & $\begin{array}{c}0.20^{* * *} \\
(0.02)\end{array}$ & & $\begin{array}{c}0.19 * * * \\
(0.02)\end{array}$ \\
\hline Foreign & & & & & $\begin{array}{c}-0.21^{* * *} \\
(0.05)\end{array}$ & & $(0.05)$ \\
\hline Risky*SR & & & & & $\begin{array}{c}0.25 * * * \\
(0.06) \\
\end{array}$ & & $\begin{array}{c}0.26 * * * \\
(0.06)\end{array}$ \\
\hline Firm FE & $\mathrm{N}$ & $\mathrm{N}$ & $\mathrm{N}$ & $\mathrm{N}$ & $\mathrm{N}$ & $\mathrm{Y}$ & $\mathrm{Y}$ \\
\hline Year FE & $\mathrm{Y}$ & $\mathrm{N}$ & $\mathrm{N}$ & $\mathrm{N}$ & $\mathrm{N}$ & $\mathrm{Y}$ & $\mathrm{Y}$ \\
\hline Observations & 24,596 & 24,596 & 23,188 & 24,596 & 23,188 & 24,596 & 23,188 \\
\hline
\end{tabular}


Table 2: Investment in fixed assets and dollar bond issuances

This table reports the results of a set of fixed effects regressions in which the dependent variable is capital expenditure over revenues and the explanatory variables are dollar bond issuer status (columns 1 and 2 use a dummy variable that takes value one if the firm has issued in a given year, columns and 4 use the dollar value of bond issuances over revenues, and columns 5 and 5 use the dollar value of outstanding bonds over revenues), leverage, returns on assets, firm size (log of total assets) and the interaction between the demanded value of the Bloomberg carry trade index (CT) and issuer status.

\begin{tabular}{lcccccc}
\hline & $(1)$ & $(2)$ & $(3)$ & $(4)$ & $(5)$ & $(6)$ \\
\hline Issuer & -0.04 & -0.04 & 0.07 & 0.08 & -0.24 & -0.15 \\
& $(0.04)$ & $(0.04)$ & $(0.26)$ & $(0.26)$ & $(0.33)$ & $(0.35)$ \\
Issuer*CT & & -0.00 & & 0.04 & & 0.03 \\
& & $(0.01)$ & & $(0.04)$ & & $(0.04)$ \\
Leverage & $-0.15^{* * *}$ & $-0.15^{* * *}$ & $-0.16^{* * *}$ & $-0.16^{* * *}$ & $-0.16^{* * *}$ & $-0.15^{* * *}$ \\
& $(0.03)$ & $(0.03)$ & $(0.03)$ & $(0.03)$ & $(0.03)$ & $(0.03)$ \\
ROA & -0.02 & -0.02 & -0.02 & -0.02 & -0.02 & -0.02 \\
& $(0.02)$ & $(0.02)$ & $(0.02)$ & $(0.02)$ & $(0.02)$ & $(0.02)$ \\
Size & $0.01^{* *}$ & $0.01^{* *}$ & $0.01^{* *}$ & $0.01^{* *}$ & $0.01^{* *}$ & $0.01^{* *}$ \\
& $(0.00)$ & $(0.00)$ & $(0.00)$ & $(0.00)$ & $(0.00)$ & $(0.00)$ \\
\hline Year FE & $\mathrm{Y}$ & $\mathrm{Y}$ & $\mathrm{Y}$ & $\mathrm{Y}$ & $\mathrm{Y}$ & $\mathrm{Y}$ \\
Firm FE & $\mathrm{Y}$ & $\mathrm{Y}$ & $\mathrm{Y}$ & $\mathrm{Y}$ & $\mathrm{Y}$ & $\mathrm{Y}$ \\
Observations & 21,220 & 21,220 & 21,220 & 21,220 & 21,220 & 21,220 \\
\hline Issuer is: & Dummy & Dummy & Amount & Amount & Amount & Amount \\
& & & Issuance & Issuance & Outstanding & Outstanding \\
\hline
\end{tabular}

Robust standard errors in parentheses, ${ }^{* * *}$ statistically significant at $1 \%,{ }^{* *}$ statistically significant at $5 \%$, and ${ }^{*}$ statistically significant at $10 \%$. 


\section{Table 3: Cash holdings and dollar bond issuances}

This table reports the results of a set of fixed effects regressions in which the dependent variable is liquid financial assets over revenues and the explanatory variables are dollar bond issuer status (columns 1 and 2 use a dummy variable that takes value one if the firm has issued in a given year, columns 3 and 4 use the dollar value of bond issuances over revenues, and columns 5 and 6 use the dollar value of outstanding bonds over revenues), leverage, returns on assets, firm size (log of total assets) and the interaction between the the Bloomberg carry trade index (CT) and issuer status.

\begin{tabular}{lcccccc}
\hline & $(1)$ & $(2)$ & $(3)$ & $(4)$ & $(5)$ & $(6)$ \\
\hline Issuer & 5.45 & 4.44 & $56.88^{* * *}$ & $52.39^{* * *}$ & $57.97^{* *}$ & $71.36^{* * *}$ \\
& $(4.02)$ & $(4.10)$ & $(15.49)$ & $(15.90)$ & $(24.04)$ & $(25.37)$ \\
Issuer*CT & & 0.88 & & 3.16 & & $4.93^{*}$ \\
& & $(0.72)$ & & $(2.53)$ & & $(2.98)$ \\
Leverage & $-43.73^{* * *}$ & $-43.75^{* * *}$ & $-43.76^{* * *}$ & $-43.78^{* * *}$ & $-43.71^{* * *}$ & $-43.76^{* * *}$ \\
& $(2.10)$ & $(2.10)$ & $(2.10)$ & $(2.10)$ & $(2.10)$ & $(2.10)$ \\
ROA & 0.72 & 0.70 & 0.62 & 0.60 & 0.69 & 0.66 \\
& $(1.29)$ & $(1.29)$ & $(1.29)$ & $(1.29)$ & $(1.29)$ & $(1.29)$ \\
Size & $5.52^{* * *}$ & $5.52^{* * *}$ & $5.48^{* * *}$ & $5.47^{* * *}$ & $5.51^{* * *}$ & $5.50^{* * *}$ \\
& $(0.27)$ & $(0.27)$ & $(0.27)$ & $(0.27)$ & $(0.27)$ & $(0.27)$ \\
\hline Year FE & $\mathrm{Y}$ & $\mathrm{Y}$ & $\mathrm{Y}$ & $\mathrm{Y}$ & $\mathrm{Y}$ & $\mathrm{Y}$ \\
Firm FE & $\mathrm{Y}$ & $\mathrm{Y}$ & $\mathrm{Y}$ & $\mathrm{Y}$ & $\mathrm{Y}$ & $\mathrm{Y}$ \\
Observations & 21,528 & 21,528 & 21,528 & 21,528 & 21,528 & 21,528 \\
\hline Issuer is: & Dummy & Dummy & Amount & Amount & Amount & Amount \\
& & & Issuance & Issuance & Outstanding & Outstanding \\
\hline
\end{tabular}

Robust standard errors in parentheses, ${ }^{* * *}$ statistically significant at $1 \%$, ${ }^{* *}$ statistically significant at $5 \%$, and * statistically significant at $10 \%$. 


\section{Table 4: Inter-firm loans holdings and dollar bond issuances}

This table reports the results of a set of fixed effects regressions in which the dependent variable is inter-firm loans over revenues and the explanatory variables are dollar bond issuer status (columns 1 and 2 us a dummy variable that takes value one if the firm has issued in a given year, columns 3 and 4 use the dollar value of bond issuances over revenues, and columns 5 and 6 use the dollar value of outstanding bonds over revenues), leverage, returns on assets, firm size (log of total assets) and the interaction between the Bloomberg carry trade index (CT) and issuer status.

\begin{tabular}{lcccccc}
\hline & $(1)$ & $(2)$ & $(3)$ & $(4)$ & $(5)$ & $(6)$ \\
\hline Issuer & $1.33^{*}$ & $1.32^{*}$ & $14.74^{* * *}$ & $18.96^{* * *}$ & $10.84^{* *}$ & $24.25^{* * *}$ \\
& $(0.78)$ & $(0.78)$ & $(3.14)$ & $(3.22)$ & $(4.90)$ & $(5.52)$ \\
Issuer*CT & & $0.36^{* * *}$ & & $2.87^{* * *}$ & & $3.46^{* * *}$ \\
& & $(0.12)$ & & $(0.51)$ & & $(0.66)$ \\
Leverage & $3.33^{* * *}$ & $3.30^{* * *}$ & $3.33^{* * *}$ & $3.27^{* * *}$ & $3.35^{* * *}$ & $3.28^{* * *}$ \\
& $(0.51)$ & $(0.51)$ & $(0.51)$ & $(0.51)$ & $(0.51)$ & $(0.51)$ \\
ROA & $-1.23^{* * *}$ & $-1.24^{* * *}$ & $-1.25^{* * *}$ & $-1.28^{* * *}$ & $-1.23^{* * *}$ & $-1.25^{* * *}$ \\
& $(0.32)$ & $(0.32)$ & $(0.31)$ & $(0.31)$ & $(0.32)$ & $(0.31)$ \\
Size & $1.31^{* * *}$ & $1.31^{* * *}$ & $1.30^{* * *}$ & $1.29^{* * *}$ & $1.31^{* * *}$ & $1.30^{* * *}$ \\
& $(0.06)$ & $(0.06)$ & $(0.06)$ & $(0.06)$ & $(0.06)$ & $(0.06)$ \\
\hline Year FE & $\mathrm{Y}$ & $\mathrm{Y}$ & $\mathrm{Y}$ & $\mathrm{Y}$ & $\mathrm{Y}$ & $\mathrm{Y}$ \\
Firm FE & $\mathrm{Y}$ & $\mathrm{Y}$ & $\mathrm{Y}$ & $\mathrm{Y}$ & $\mathrm{Y}$ & $\mathrm{Y}$ \\
Observations & 22,163 & 22,163 & 22,163 & 22,163 & 22,163 & 22,163 \\
\hline Issuer is: & Dummy & Dummy & Amount & Amount & Amount & Amount \\
& & & Issuance & Issuance & Outstanding & Outstanding \\
\hline
\end{tabular}

Robust standard errors in parentheses, ${ }^{* * *}$ statistically significant at $1 \%$, ${ }^{* *}$ statistically significant at $5 \%$, and * statistically significant at $10 \%$. 


\section{Table 5: Inter-firm loans and dollar and RMB bond issuances}

This table reports the results of a set of fixed effects regressions in which the dependent variable is inter-firms loans over revenues and the explanatory variables are dollar bond issuer status (Issuer USD columns 1 and 2 use a dummy variable that takes value one if the firm has issued in a given year, columns 3 and 4 use the value of bond issuances over revenues, and columns 5 and 5 use the value of outstanding bonds over revenues), RMB bond issuer status (Issuer RMB columns 1 and 2 use a dummy variable that takes value one if the firm has issued in a given year, columns 3 and 4 use the value of bond issuances over revenues, and columns 5 and 5 use the value of outstanding bonds over revenues) leverage, returns on assets, firm size (log of total assets) and the interaction between the Bloomberg carry trade index (CT) and issuer status.

\begin{tabular}{|c|c|c|c|c|c|c|}
\hline & (1) & $(2)$ & (3) & (4) & (5) & (6) \\
\hline Issuer USD & $\begin{array}{c}1.23 \\
(0.79)\end{array}$ & $\begin{array}{c}1.23 \\
(0.79)\end{array}$ & $\begin{array}{c}14.70^{* * * *} \\
(3.14)\end{array}$ & $\begin{array}{c}18.79 * * * \\
(3.22)\end{array}$ & $\begin{array}{c}10.20^{* *} \\
(4.91)\end{array}$ & $\begin{array}{c}23.46^{* * *} \\
(5.58)\end{array}$ \\
\hline Issuer RMB & $\begin{array}{c}0.47 \\
(0.30)\end{array}$ & $\begin{array}{c}0.31 \\
(0.39)\end{array}$ & $\begin{array}{c}0.20 \\
(0.31)\end{array}$ & $\begin{array}{c}0.15 \\
(0.31)\end{array}$ & $\begin{array}{c}0.11 \\
(0.07)\end{array}$ & $\begin{array}{c}0.10 \\
(0.14)\end{array}$ \\
\hline Issuer USD*CT & & $\begin{array}{c}0.38 * * * \\
(0.12)\end{array}$ & & $\begin{array}{c}2.85 * * * \\
(0.47)\end{array}$ & & $\begin{array}{c}3.38 * * * \\
(0.66)\end{array}$ \\
\hline Issuer RMB*CT & & $\begin{array}{c}0.03 \\
(0.05)\end{array}$ & & $\begin{array}{c}0.14 \\
(0.10)\end{array}$ & & $\begin{array}{l}-0.00 \\
(0.01)\end{array}$ \\
\hline Leverage & $\begin{array}{c}3.94 * * * \\
(0.52)\end{array}$ & $\begin{array}{c}3.89 * * * \\
(0.52)\end{array}$ & $\begin{array}{c}3.34 * * * \\
(0.51)\end{array}$ & $\begin{array}{c}3.26 * * * \\
(0.51)\end{array}$ & $\begin{array}{c}3.35 * * * \\
(0.51)\end{array}$ & $\begin{array}{c}3.28 * * * \\
(0.51)\end{array}$ \\
\hline ROA & $\begin{array}{c}-5.49 * * * \\
(0.29)\end{array}$ & $\begin{array}{c}-5.50 * * * \\
(0.29)\end{array}$ & $\begin{array}{c}-1.25^{* * *} \\
(0.31)\end{array}$ & $\begin{array}{c}-1.28 * * * \\
(0.31)\end{array}$ & $\begin{array}{c}-1.24^{* * *} \\
(0.32)\end{array}$ & $\begin{array}{c}-1.25 * * * \\
(0.31)\end{array}$ \\
\hline Size & $\begin{array}{c}-1.02 * * * \\
(0.15)\end{array}$ & $\begin{array}{c}-1.02^{* * *} \\
(0.15)\end{array}$ & $\begin{array}{c}1.30 * * * \\
(0.06)\end{array}$ & $\begin{array}{c}1.29 * * * \\
(0.06)\end{array}$ & $\begin{array}{c}1.31^{* * *} \\
(0.06)\end{array}$ & $\begin{array}{c}1.30 * * * \\
(0.06)\end{array}$ \\
\hline Year FE & $\mathrm{Y}$ & $\mathrm{Y}$ & $\mathrm{Y}$ & $\mathrm{Y}$ & $\mathrm{Y}$ & $\mathrm{Y}$ \\
\hline Firm FE & $\mathrm{Y}$ & $\mathrm{Y}$ & $\mathrm{Y}$ & $\mathrm{Y}$ & $\mathrm{Y}$ & $\mathrm{Y}$ \\
\hline Observations & 22,163 & 22,163 & 22,163 & 22,163 & 22,163 & 22,163 \\
\hline Issuer is: & Dummy & Dummy & $\begin{array}{l}\text { Amount } \\
\text { Issuance }\end{array}$ & $\begin{array}{l}\text { Amount } \\
\text { Issuance }\end{array}$ & $\begin{array}{c}\text { Amount } \\
\text { Outstanding }\end{array}$ & $\begin{array}{c}\text { Amount } \\
\text { Outstanding }\end{array}$ \\
\hline
\end{tabular}


Table 6: Inter-firm loan holdings and dollar bond issuances: intensive versus extensive margin

This table reports the results of a set of fixed effects regressions in which the dependent variable is inter-firm loans over revenues and the explanatory variables are dollar bond issuer status (Issuer dummy is a dummy variable that takes value one if the firm has issued in a given year), amount issued (in columns 1 and 2 Issuer amount is the dollar value of bond issuances over revenues and in columns 3 and 4 use Issuer amount as the dollar value of outstanding bonds over revenues), leverage, returns on assets, firm size (log of total assets) and the interaction between the Bloomberg carry trade index (CT) and issuer status and amount.

\begin{tabular}{lcccc}
\hline & $(1)$ & $(2)$ & $(3)$ & $(4)$ \\
\hline Issuer Dummy & 0.23 & 0.37 & 0.68 & 0.12 \\
& $(0.82)$ & $(0.82)$ & $(0.88)$ & $(0.89)$ \\
Issuer Dummy *CT & & 0.15 & & 0.10 \\
& & $(0.14)$ & & $(0.15)$ \\
Issuer amount & $14.45^{* * *}$ & $18.60^{* * *}$ & 8.86 & $23.41^{* * *}$ \\
& $(3.30)$ & $(3.37)$ & $(5.54)$ & $(6.25)$ \\
Issuer amount * CT & & $2.64^{* * *}$ & & $3.16^{* * *}$ \\
& & $(0.52)$ & & $(0.78)$ \\
Leverage & $3.33^{* * *}$ & $3.25^{* * *}$ & $3.33^{* * *}$ & $3.27^{* * *}$ \\
& $(0.51)$ & $(0.51)$ & $(0.51)$ & $(0.51)$ \\
ROA & $-1.25^{* * *}$ & $-1.28^{* * *}$ & $-1.23^{* * *}$ & $-1.25^{* * *}$ \\
& $(0.31)$ & $(0.31)$ & $(0.32)$ & $(0.31)$ \\
Size & $1.31^{* * *}$ & $1.29^{* * *}$ & $1.31^{* * *}$ & $1.30^{* * *}$ \\
& $(0.06)$ & $(0.06)$ & $(0.06)$ & $(0.06)$ \\
\hline Year FE & $\mathrm{Y}$ & $\mathrm{Y}$ & $\mathrm{Y}$ & $\mathrm{Y}$ \\
Firm FE & $\mathrm{Y}$ & $\mathrm{Y}$ & $\mathrm{Y}$ & $\mathrm{Y}$ \\
Observations & 22,163 & 22,163 & 22,163 & 22,163 \\
Issuer amount is: & Issuances & Issuances & Outstanding & Outstanding \\
\hline
\end{tabular}

Robust standard errors in parentheses, *** statistically significant at $1 \%$, ** statistically significant at $5 \%$, and * statistically significant at $10 \%$. 
Table 7: Inter-firm loan holdings and dollar bond issuances

This table reports the results of a set of fixed effects regressions in which the dependent variable is inter-firm loans over revenues and the explanatory variables are dollar bond issuer status (columns 1 and 2 use a dummy variable that takes value one if the firm has issued in a given year, columns 3 and 4 use the dollar value of bond issuances over revenues, and columns 5 and 6 use the dollar value of outstanding bonds over revenues), leverage, returns on assets, firm size (log of total assets) and the interaction between the shadow rate dummy and issuer status.

\begin{tabular}{|c|c|c|c|c|c|c|}
\hline & (1) & (2) & (3) & (4) & (5) & (6) \\
\hline \multirow[t]{2}{*}{ Issuer } & $1.33^{*}$ & -0.003 & $14.74 * * *$ & -0.019 & $10.84 * *$ & -0.047 \\
\hline & $(0.78)$ & $(0.014)$ & (3.14) & $(0.048)$ & $(4.90)$ & $(0.066)$ \\
\hline \multirow[t]{2}{*}{ Issuer*SR } & & $0.027^{*}$ & & $0.225^{* * *}$ & & $0.295 * * *$ \\
\hline & & $(0.015)$ & & $(0.059)$ & & $(0.087)$ \\
\hline \multirow[t]{2}{*}{ Leverage } & $3.33^{* * *}$ & $0.033^{* * *}$ & $3.33^{* * *}$ & $0.034 * * *$ & $3.35 * * *$ & $0.034 * * *$ \\
\hline & $(0.51)$ & $(0.005)$ & $(0.51)$ & $(0.005)$ & $(0.51)$ & $(0.005)$ \\
\hline \multirow[t]{2}{*}{ ROA } & $-1.23 * * *$ & $-0.014 * * *$ & $-1.25 * * *$ & $-0.015 * * *$ & $-1.23 * * *$ & $-0.015^{* * *}$ \\
\hline & $(0.32)$ & $(0.004)$ & $(0.31)$ & $(0.004)$ & $(0.32)$ & $(0.004)$ \\
\hline \multirow[t]{2}{*}{ Size } & $1.31^{* * *}$ & $0.015^{* * *}$ & $1.30 * * *$ & $0.015^{* * *}$ & $1.31^{* * *}$ & $0.015 * * *$ \\
\hline & $(0.06)$ & $(0.001)$ & $(0.06)$ & $(0.001)$ & $(0.06)$ & $(0.001)$ \\
\hline Year FE & $\mathrm{Y}$ & $\mathrm{Y}$ & $\mathrm{Y}$ & $\mathrm{Y}$ & $\mathrm{Y}$ & $\mathrm{Y}$ \\
\hline Firm FE & $\mathrm{Y}$ & $\mathrm{Y}$ & $\mathrm{Y}$ & $\mathrm{Y}$ & $\mathrm{Y}$ & $\mathrm{Y}$ \\
\hline Observations & 22,163 & 22,163 & 22,163 & 22,163 & 22,163 & 22,163 \\
\hline \multirow[t]{2}{*}{ Issuer is: } & Dummy & Dummy & Amount & Amount & Amount & Amount \\
\hline & & & Issuance & Issuance & Outstanding & Outstanding \\
\hline SR is: & \multicolumn{6}{|c|}{ Dummy (above median $=1$, below median $=0$ ) } \\
\hline
\end{tabular}

Robust standard errors in parentheses, ${ }^{* * *}$ statistically significant at $1 \%$, ${ }^{* *}$ statistically significant at $5 \%$, and ${ }^{*}$ statistically significant at $10 \%$. 


\section{Table 8: Inter-firm loan holdings and dollar bond issuances}

This table reports the results of a set of fixed effects regressions in which the dependent variable is inter-firm loans over total assets and the explanatory variables are dollar bond issuer status (columns 1 and 2 us a dummy variable that takes value one if the firm has issued in a given year, columns 3 and 4 use the dollar value of bond issuances over total assets, and columns 5 and 6 use the dollar value of outstanding bonds over total assets), leverage, returns on assets, firm size (log of total assets) and the interaction between the shadow rate dummy and issuer status.

\begin{tabular}{|c|c|c|c|c|c|c|}
\hline & (1) & (2) & (3) & (4) & (5) & (6) \\
\hline \multirow[t]{2}{*}{ Issuer } & $0.74 * * *$ & 0.41 & 0.28 & 7.07 & 2.11 & 0.97 \\
\hline & $(0.23)$ & $(0.31)$ & (4.65) & $(5.07)$ & (4.43) & $(4.45)$ \\
\hline \multirow[t]{2}{*}{ Issuer*SR } & & 0.06 & & $2.48 * * *$ & & $1.53 * * *$ \\
\hline & & $(0.04)$ & & $(0.02)$ & & $(0.57)$ \\
\hline \multirow[t]{2}{*}{ Leverage } & $0.07 * * *$ & $0.07 * * *$ & $0.07 * * *$ & $0.07 * * *$ & $0.07 * * *$ & $0.07 * * *$ \\
\hline & $(0.02)$ & $(0.02)$ & $(0.02)$ & $(0.02)$ & $(0.02)$ & $(0.02)$ \\
\hline \multirow[t]{2}{*}{ ROA } & $-0.26 * * *$ & $-0.26 * * *$ & $-0.25 * * *$ & $-0.25^{* * *}$ & $-0.26 * * *$ & $-0.25 * * *$ \\
\hline & $(0.09)$ & $(0.09)$ & (0.09) & $(0.09)$ & (0.09) & (0.09) \\
\hline \multirow[t]{2}{*}{ Size } & $0.05^{* *}$ & $0.05^{* *}$ & $0.05 * *$ & $0.04^{* *}$ & $0.05^{* *}$ & $0.05^{* *}$ \\
\hline & $(0.02)$ & $(0.02)$ & $(0.02)$ & $(0.02)$ & $(0.02)$ & $(0.02)$ \\
\hline Year FE & $\mathrm{Y}$ & $\mathrm{Y}$ & $\mathrm{Y}$ & $\mathrm{Y}$ & $\mathrm{Y}$ & $\mathrm{Y}$ \\
\hline Firm FE & $\mathrm{Y}$ & Y & $\mathrm{Y}$ & $\mathrm{Y}$ & Y & $\mathrm{Y}$ \\
\hline Observations & 26,297 & 26,297 & 26,297 & 26,297 & 26,297 & 26,297 \\
\hline \multirow[t]{2}{*}{ Issuer is: } & Dummy & Dummy & Amount & Amount & Amount & Amount \\
\hline & & & Issuance & Issuance & Outstanding & Outstanding \\
\hline SR is: & \multicolumn{6}{|c|}{ Dummy (above median $=1$, below median $=0$ ) } \\
\hline
\end{tabular}




\section{Table 9: Inter-firm loans and dollar and RMB bond issuances}

This table reports the results of a set of fixed effects regressions in which the dependent variable is inter-firm loans over total assets and the explanatory variables are dollar bond issuer status (Issuer USD columns 1 and 2 use a dummy variable that takes value one if the firm has issued in a given year, columns 3 and 4 use the value of bond issuances over total assets, and columns 5 and 6 use the value of outstanding bonds over total assets), RMB bond issuer status (Issuer RMB columns 1 and 2 use a dummy variable that takes value one if the firm has issued in a given year, columns 3 and 4 use the value of bond issuances over total assets, and columns 5 and 6 use the value of outstanding bonds over total assets) leverage, returns on assets, firm size (log of total assets) and the interaction between the Bloomberg carry trade index (CT) and issuer status.

\begin{tabular}{|c|c|c|c|c|c|c|}
\hline & $(1)$ & $(2)$ & (3) & (4) & (5) & (6) \\
\hline Issuer USD & $\begin{array}{c}0.74 * * * \\
(0.23)\end{array}$ & $\begin{array}{c}0.41 \\
(0.31)\end{array}$ & $\begin{array}{c}0.08 \\
(4.56)\end{array}$ & $\begin{array}{c}6.91 \\
(5.01)\end{array}$ & $\begin{array}{c}1.77 \\
(4.33)\end{array}$ & $\begin{array}{c}0.69 \\
(4.35)\end{array}$ \\
\hline Issuer RMB & $\begin{array}{c}0.26^{* * * *} \\
(0.09)\end{array}$ & $\begin{array}{c}0.19 \\
(0.12)\end{array}$ & $\begin{array}{c}0.06 \\
(0.09)\end{array}$ & $\begin{array}{c}0.03 \\
(0.09)\end{array}$ & $\begin{array}{c}0.03 \\
(0.02)\end{array}$ & $\begin{array}{c}0.02 \\
(0.04)\end{array}$ \\
\hline Issuer USD*CT & & $\begin{array}{c}0.05 \\
(0.04)\end{array}$ & & $\begin{array}{c}2.44 * * * \\
(0.73)\end{array}$ & & $\begin{array}{c}1.46 * * * \\
(0.56)\end{array}$ \\
\hline Issuer RMB*CT & & $\begin{array}{c}0.01 \\
(0.01)\end{array}$ & & $\begin{array}{c}0.04 \\
(0.03)\end{array}$ & & $\begin{array}{c}0.00 \\
(0.00)\end{array}$ \\
\hline Leverage & $\begin{array}{c}0.08^{* * * *} \\
(0.02)\end{array}$ & $\begin{array}{c}0.08 * * * \\
(0.02)\end{array}$ & $\begin{array}{c}0.05 * * \\
(0.02)\end{array}$ & $\begin{array}{l}0.05^{* *} \\
(0.02)\end{array}$ & $\begin{array}{c}0.05^{* *} \\
(0.02)\end{array}$ & $\begin{array}{l}0.05^{* *} \\
(0.02)\end{array}$ \\
\hline ROA & $\begin{array}{c}-0.58 * * * \\
(0.08)\end{array}$ & $\begin{array}{c}-0.59 * * * \\
(0.08)\end{array}$ & $\begin{array}{c}-0.22 * * \\
(0.09)\end{array}$ & $\begin{array}{c}-0.22 * * \\
(0.09)\end{array}$ & $\begin{array}{c}-0.22 * * \\
(0.09)\end{array}$ & $\begin{array}{c}-0.22^{* *} \\
(0.09)\end{array}$ \\
\hline Size & $\begin{array}{c}-0.26 * * * \\
(0.04)\end{array}$ & $\begin{array}{c}-0.26^{* * *} \\
(0.04)\end{array}$ & $\begin{array}{c}0.05 * * \\
(0.02)\end{array}$ & $\begin{array}{c}0.04 * * \\
(0.02)\end{array}$ & $\begin{array}{l}0.05^{* *} \\
(0.02)\end{array}$ & $\begin{array}{l}0.05^{* *} \\
(0.02)\end{array}$ \\
\hline Year FE & $\mathrm{Y}$ & $\mathrm{Y}$ & $\mathrm{Y}$ & $\mathrm{Y}$ & $\mathrm{Y}$ & $\mathrm{Y}$ \\
\hline $\begin{array}{l}\text { Firm FE } \\
\text { Observations }\end{array}$ & $\begin{array}{c}\mathrm{Y} \\
26,297\end{array}$ & $\begin{array}{c}\mathrm{Y} \\
26,297\end{array}$ & $\begin{array}{c}\mathrm{Y} \\
22,175\end{array}$ & $\begin{array}{c}\mathrm{Y} \\
22,175\end{array}$ & $\begin{array}{c}\mathrm{Y} \\
22,175\end{array}$ & $\begin{array}{c}\mathrm{Y} \\
22,175\end{array}$ \\
\hline Issuer is: & Dummy & Dummy & $\begin{array}{l}\text { Amount } \\
\text { Issuance }\end{array}$ & $\begin{array}{l}\text { Amount } \\
\text { Issuance }\end{array}$ & $\begin{array}{c}\text { Amount } \\
\text { Outstanding }\end{array}$ & $\begin{array}{c}\text { Amount } \\
\text { Outstanding }\end{array}$ \\
\hline
\end{tabular}




\section{Table 10: Inter-firm loans, dollar bond issuance and firm heterogeneity}

This table reports the results of a set of fixed effects regressions in which the dependent variable is inter-firm loans over revenues and the explanatory variables are dollar bond issuer status (Issuer dummy is a dummy variable that takes value one if the firm has issued in a given year), amount issued (in columns 1-3 Issuer amount is the dollar value of bond issuances over revenues and in columns 3-6 Issuer amount is the dollar value of outstanding bonds over revenues), leverage, returns on assets, firm size (log of total assets) and the interaction between firm characteristics (return on assets, risky firms and Tobin's Q, using sample average of each firm) and each of issuer status and issuer amount.

\begin{tabular}{lcccccc}
\hline & $(1)$ & $(2)$ & $(3)$ & $(4)$ & $(5)$ & $(6)$ \\
\hline Issuer Dummy & 0.72 & $1.45^{*}$ & 0.68 & 0.94 & 1.29 & $1.58^{*}$ \\
& $(0.82)$ & $(0.84)$ & $(0.86)$ & $(0.88)$ & $(0.89)$ & $(0.94)$ \\
Issuer amount & $7.67^{* *}$ & -2.52 & -7.11 & 5.06 & 0.25 & $-21.99 * * *$ \\
& $(3.52)$ & $(3.91)$ & $(4.38)$ & $(5.63)$ & $(5.79)$ & $(7.24)$ \\
Issuer Dummy x FC & $6.12^{* * *}$ & $-2.66^{* * *}$ & $-0.24^{*}$ & $5.97 * * *$ & $-2.72^{* * *}$ & $-0.33^{* *}$ \\
& $(1.66)$ & $(0.93)$ & $(0.14)$ & $(1.77)$ & $(1.01)$ & $(0.15)$ \\
Issuer amount X FC & $-35.28^{* * *}$ & $35.57 * * *$ & $1.50 * * *$ & $-41.74 * * *$ & $35.84 * * *$ & $3.40^{* * *}$ \\
& $(6.17)$ & $(4.38)$ & $(0.18)$ & $(10.89)$ & $(7.03)$ & $(0.38)$ \\
Leverage & $3.32^{* * *}$ & $3.25^{* * *}$ & -0.09 & $3.33^{* * *}$ & $3.28^{* * *}$ & -0.09 \\
& $(0.51)$ & $(0.51)$ & $(0.99)$ & $(0.51)$ & $(0.51)$ & $(0.99)$ \\
ROA & $-1.26 * * *$ & $-1.28^{* * *}$ & $-1.07 *$ & $-1.25 * * *$ & $-1.26 * * *$ & $-1.08^{*}$ \\
Size & $(0.31)$ & $(0.32)$ & $(0.61)$ & $(0.32)$ & $(0.32)$ & $(0.61)$ \\
& $1.30^{* * *}$ & $1.29 * * *$ & $1.14 * * *$ & $1.31 * * *$ & $1.30 * * *$ & $1.13^{* * *}$ \\
Firm FE & $(0.06)$ & $(0.07)$ & $(0.11)$ & $(0.06)$ & $(0.07)$ & $(0.11)$ \\
Observations & $\mathrm{Y}$ & $\mathrm{Y}$ & $\mathrm{Y}$ & $\mathrm{Y}$ & $\mathrm{Y}$ & $\mathrm{Y}$ \\
\hline Yssuer amount is: & $\mathrm{Y}$ & $\mathrm{Y}$ & $\mathrm{Y}$ & $\mathrm{Y}$ & $\mathrm{Y}$ & $\mathrm{Y}$ \\
\hline Fear FE & 22,163 & 21,995 & 7,470 & 22,163 & 21,995 & 7,470 \\
\hline
\end{tabular}

Robust standard errors in parentheses, *** statistically significant at $1 \%$, ** statistically significant at $5 \%$, and $*$ statistically significant at $10 \%$. 
Table 11: NFC USD Bond Issuance and Outstanding by Industry

Panel A: USD Bond Issuance by NFC

\begin{tabular}{|c|c|c|}
\hline Sector & Billion USD & $\%$ \\
\hline Oil and Gas & 33.00 & 22 \\
\hline Real Estate & 15.02 & 13 \\
\hline Utilities & 10.67 & 12 \\
\hline Constructions & 5.18 & 12 \\
\hline Holding Companies & 0.80 & 7 \\
\hline \multicolumn{3}{|c|}{ Panel B: USD Bond Outstanding by NFC } \\
\hline & Billion USD (2016) & $\%$ \\
\hline Oil and Gas & 166.02 & 34 \\
\hline Real Estate & 92.29 & 19 \\
\hline Computers & 73.47 & 15 \\
\hline Utilities & 44.93 & 9 \\
\hline Constructions & 22.14 & 5 \\
\hline
\end{tabular}

Source: Dealogic 


\section{Table 12: Inter-firm loans as regulatory arbitrage}

This table shows the results of a set of firm-level regressions in which the dependent variable is inter-firm loans over revenues and the explanatory variables are either dollar issuer status (Treatment in column 1) or risky firm status (Treatment in columns 2 and 3) a dummy that takes a value 1 after 2008 (Policy) and various interactions among these variables.

\begin{tabular}{|c|c|c|c|c|}
\hline & $(1)$ & $(2)$ & (3) & (4) \\
\hline \multirow[t]{2}{*}{ Treatment } & $-1.99 * *$ & $2.73^{* * *}$ & -3.97 & -0.71 \\
\hline & $(0.80)$ & $(0.26)$ & (4.53) & (3.54) \\
\hline \multirow[t]{2}{*}{ Policy } & $-2.25 * * *$ & $-2.10 * * *$ & $-2.11 * * *$ & $-2.29 * * *$ \\
\hline & $(0.16)$ & $(0.18)$ & $(0.18)$ & $(0.41)$ \\
\hline \multirow[t]{2}{*}{ Treatment* Policy } & $2.71 * * *$ & 0.14 & & \\
\hline & $(0.87)$ & $(0.36)$ & & \\
\hline \multirow[t]{2}{*}{ USD Issuer } & & & 3.26 & \\
\hline & & & (3.58) & \\
\hline \multirow[t]{2}{*}{ USD Issuer * Policy } & & & -1.88 & \\
\hline & & & (3.93) & \\
\hline \multirow[t]{2}{*}{ Risky Sector } & & & $2.74 * * *$ & \\
\hline & & & $(0.26)$ & \\
\hline \multirow[t]{2}{*}{ Risky Sector * Policy } & & & -0.19 & \\
\hline & & & $(0.37)$ & \\
\hline \multicolumn{5}{|l|}{ USD Issuer * Risky } \\
\hline \multirow[t]{2}{*}{ Sector * Policy } & & & $9.92 * *$ & $8.04^{* *}$ \\
\hline & & & (4.93) & (3.80) \\
\hline Observations & 24,596 & 24,596 & 24,596 & 6,208 \\
\hline Treatment is & USD Issuer & Risky Sector & Risky USD Issuer & $\begin{array}{c}\text { USD Issuer in } \\
\text { Risky Subsample }\end{array}$ \\
\hline
\end{tabular}


Figure 1: International Bonds issued by Chinese Non-Financial Corporates

Total Issuance and Carry Trade Index

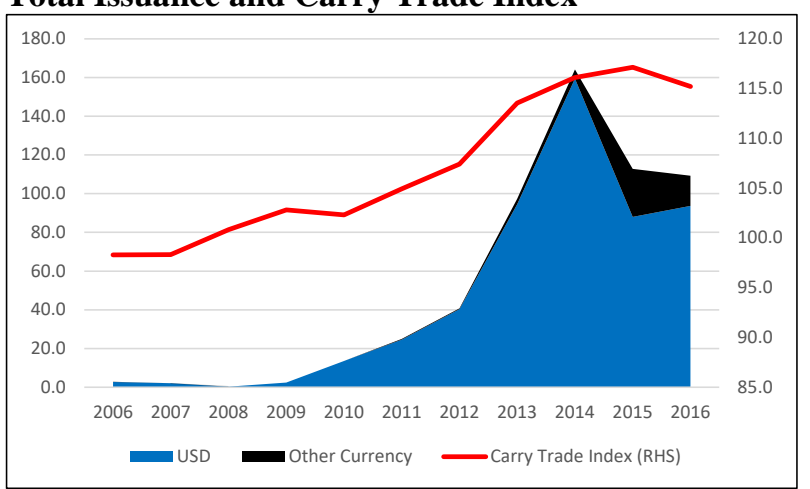

Gross outstanding and Carry Trade Index

Total Issuance and Shadow Rate

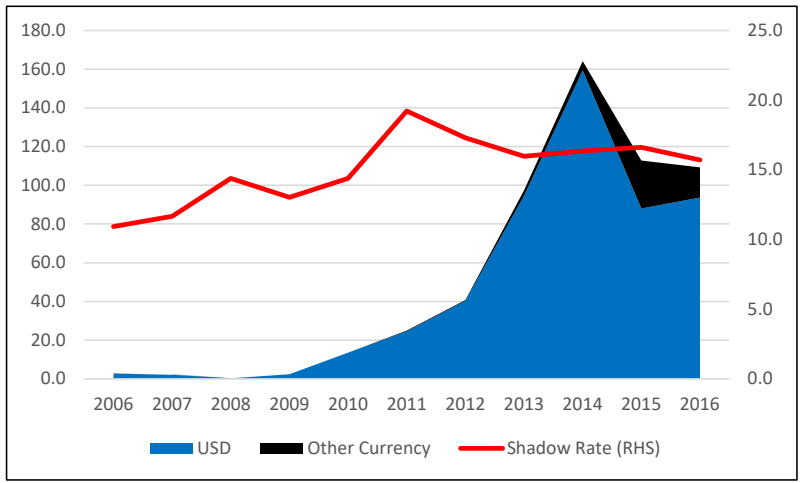

Total Outstanding and Shadow Rate

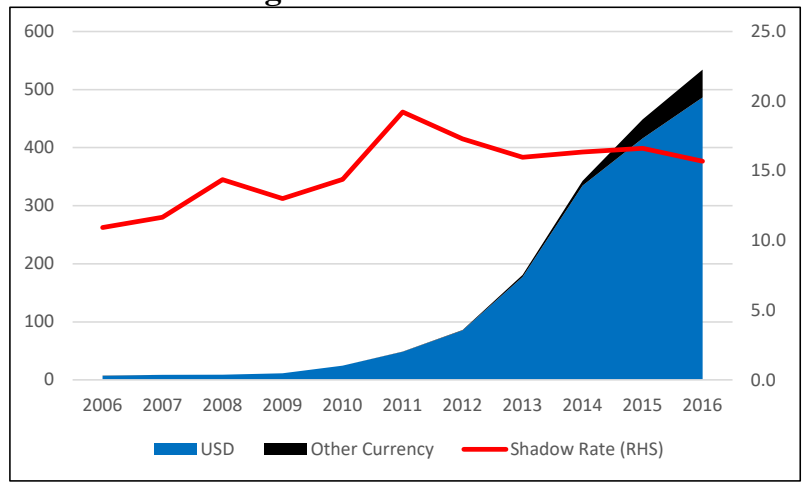

Gross issuance and FX

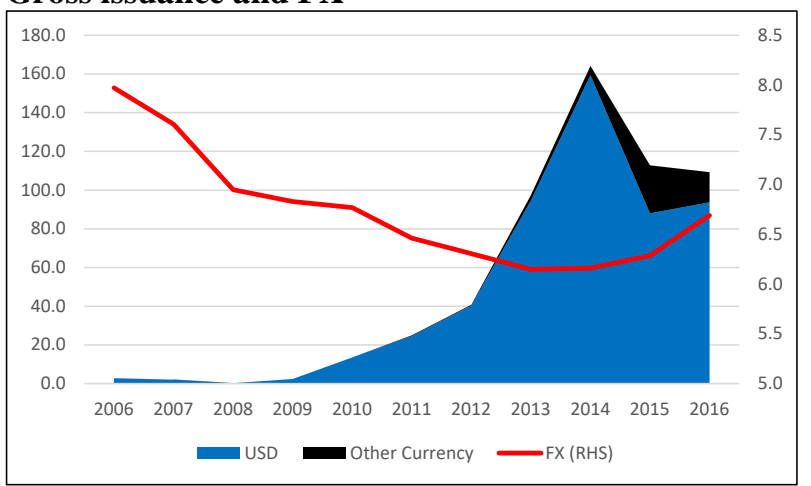

Gross outstanding and FX

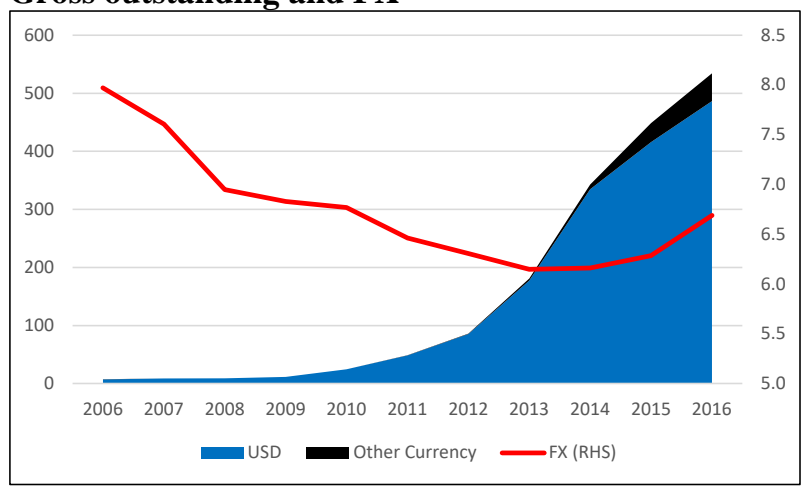


Figure 2A: International bonds by Chinese Residents and Chinese Nationals Offshore Bond Outstanding

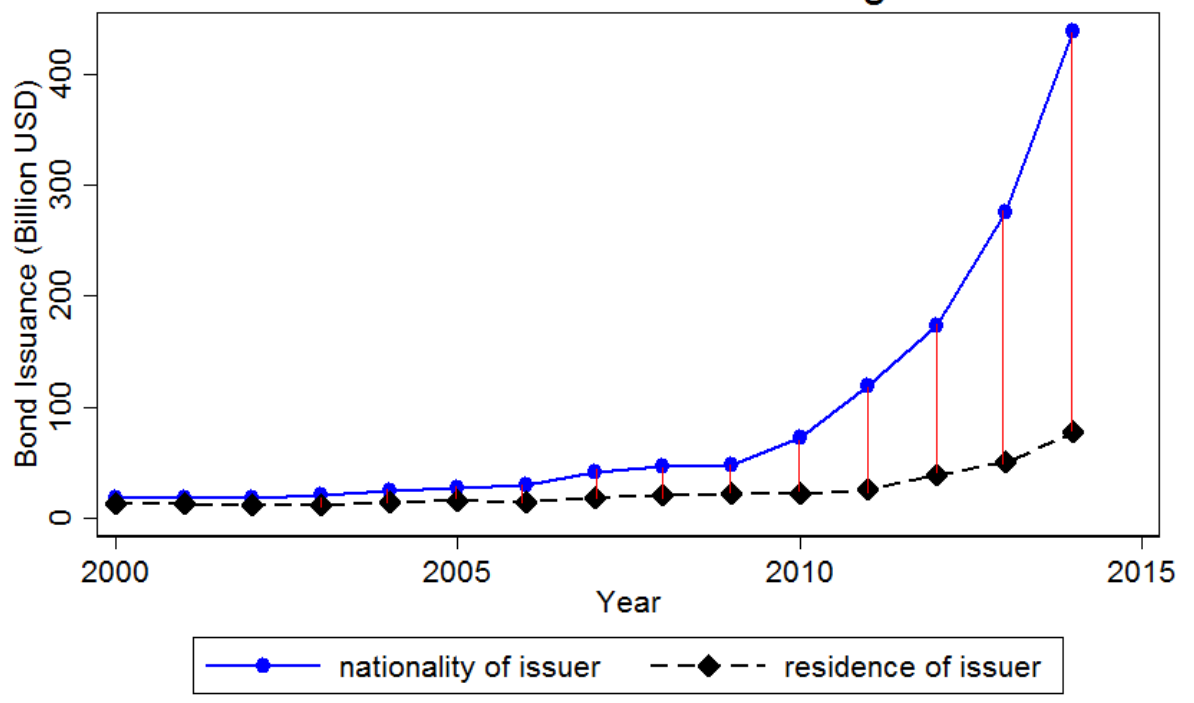

Residence of issuer: the Chinese citizen/ firm/ bank issue the bond in China

Data Source: BIS, 2016

Figure 2B: Dealogic versus BIS data

Foreign Bond Outstanding: BIS vs.Dealogic

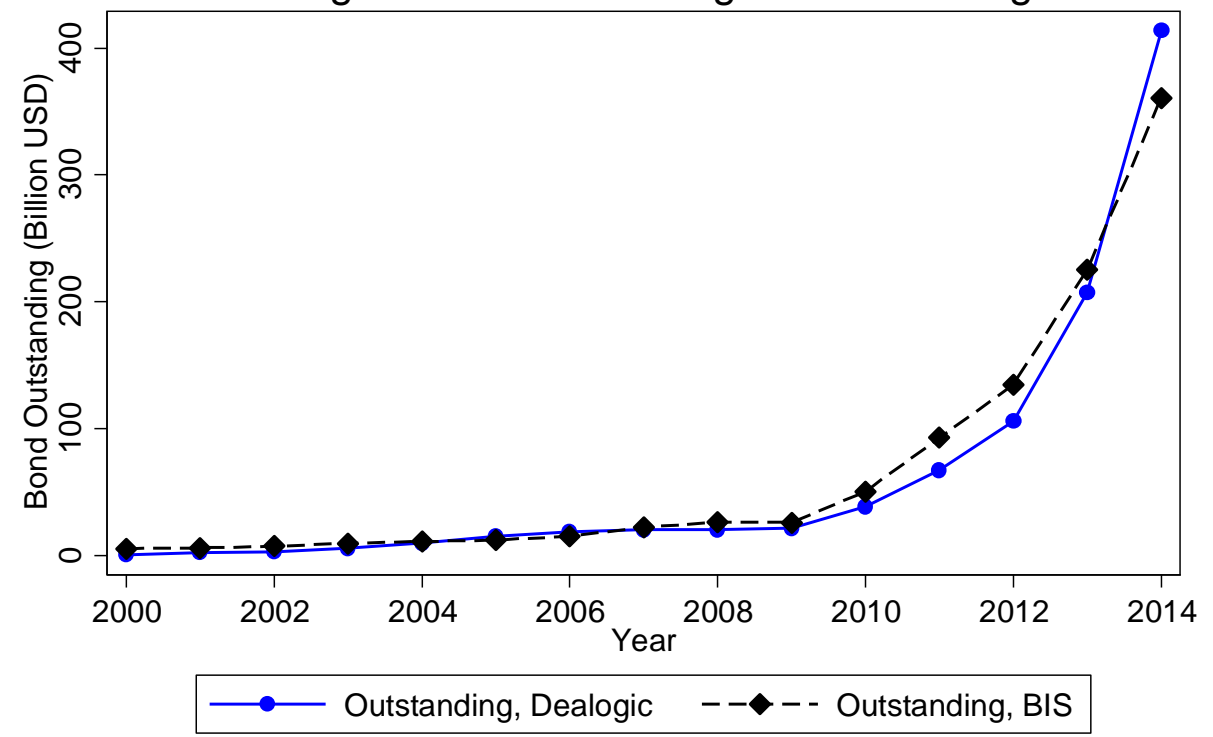

Data Source: BIS, Dealogic 
Figure 3: NFC bond issuances and outstanding by currency
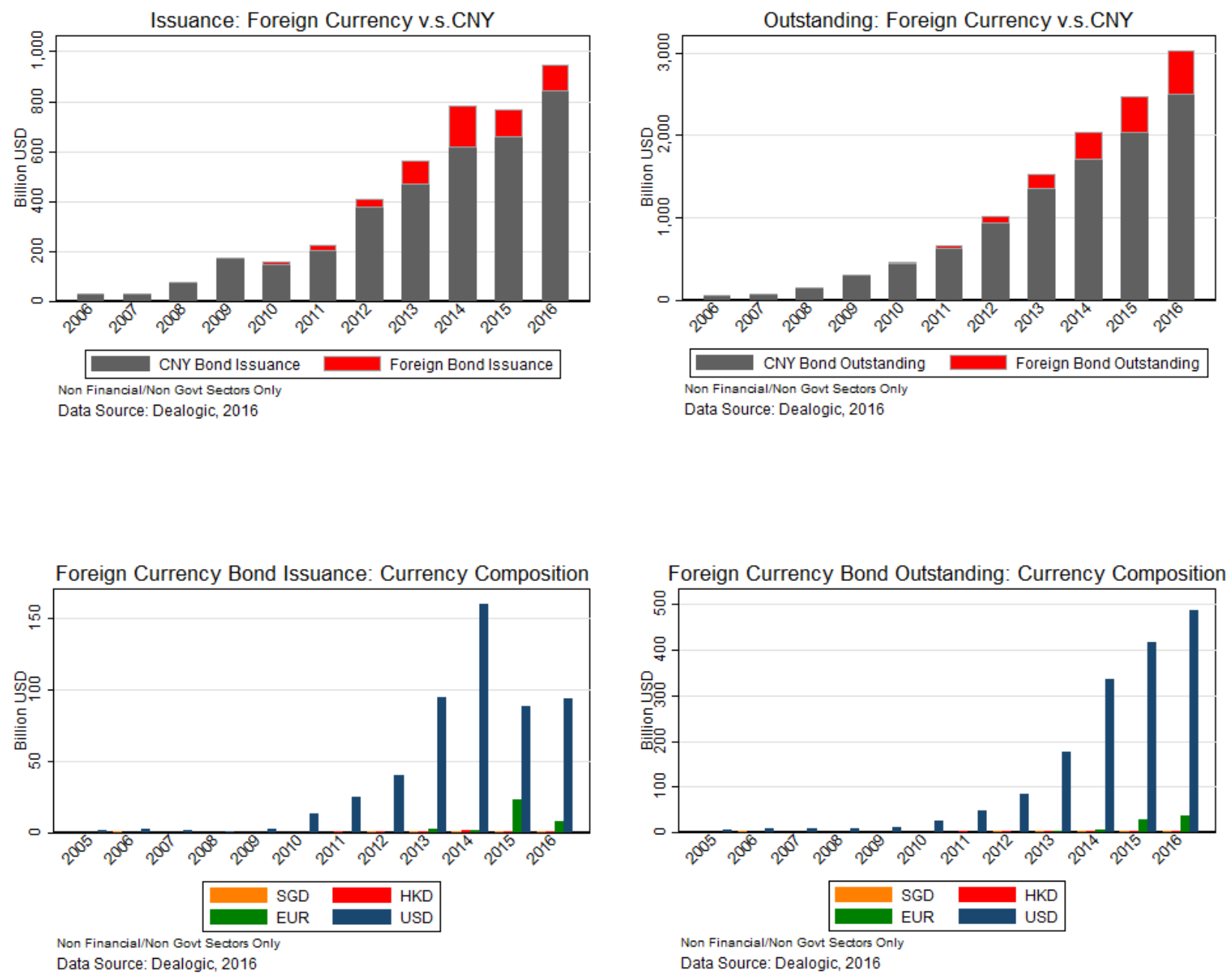
Figure 4: Year fixed effects and returns from carry trade

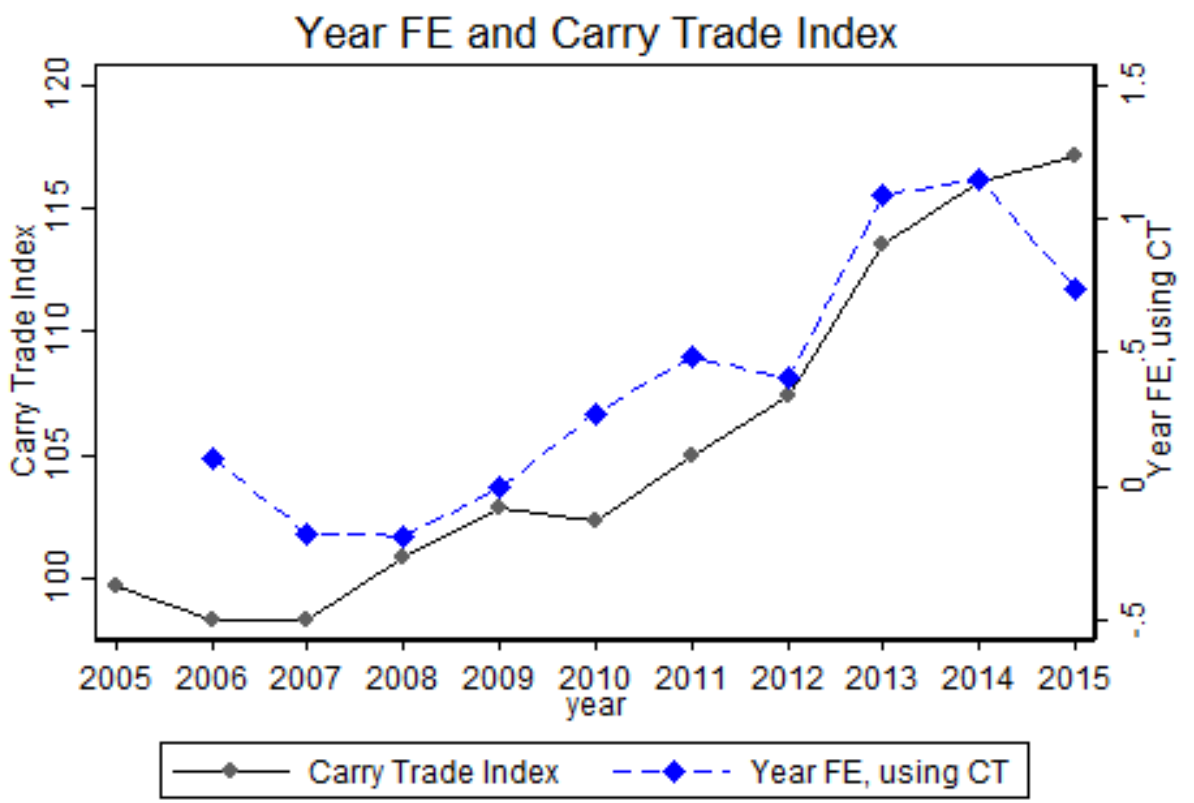

Data Source: Dealogic, CSMAR, RESSET, Bloomberg

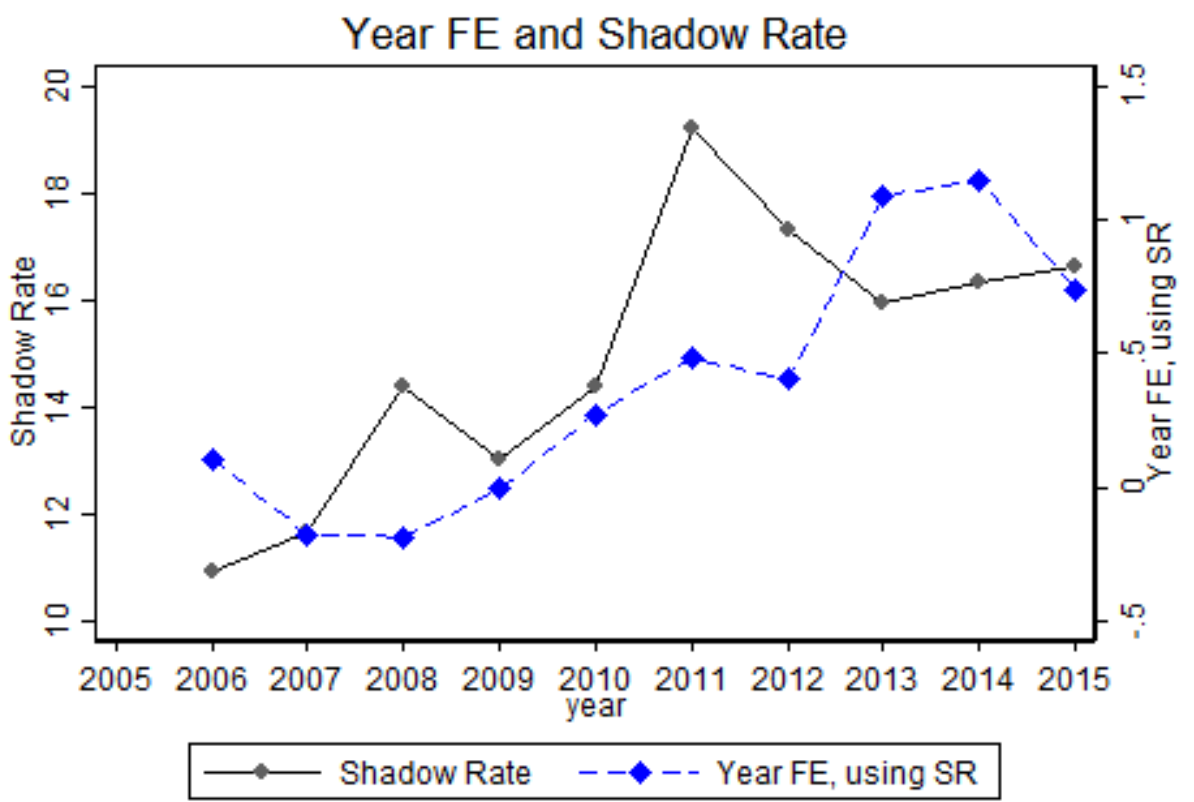

Data Source: Dealogic, CSMAR, RESSET, Bloomberg

These two figures plot the year fixed effects recovered from the regression of Column 1 of Table 1 against the Bloomberg carry trade index (top panel) and shadow rate of private lending interest rate in the Chinese shadow banking system 
Figure 5: NFC inter-firm loan and provision rate by sector

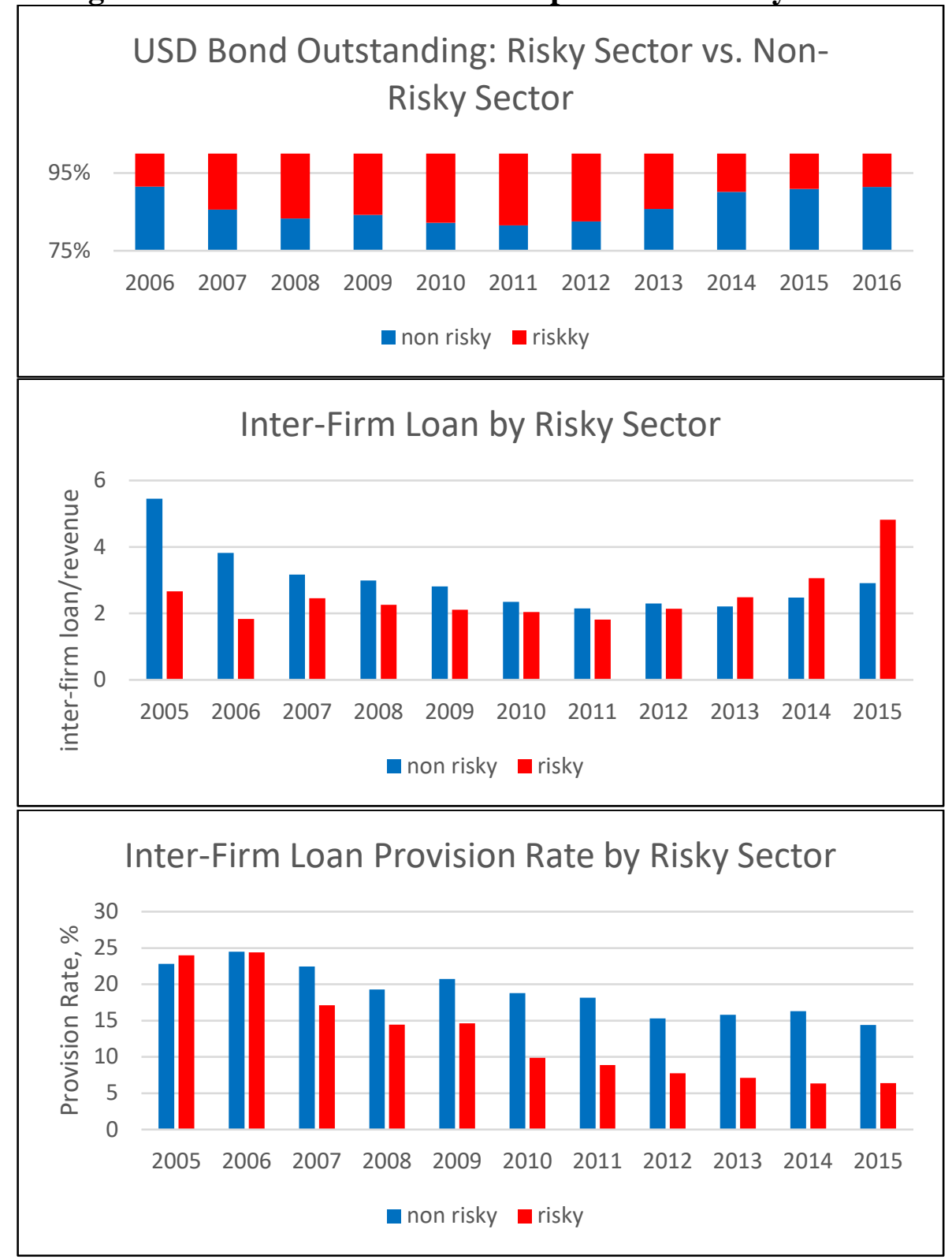


Figure 6: Inter-firm loan and provision rate

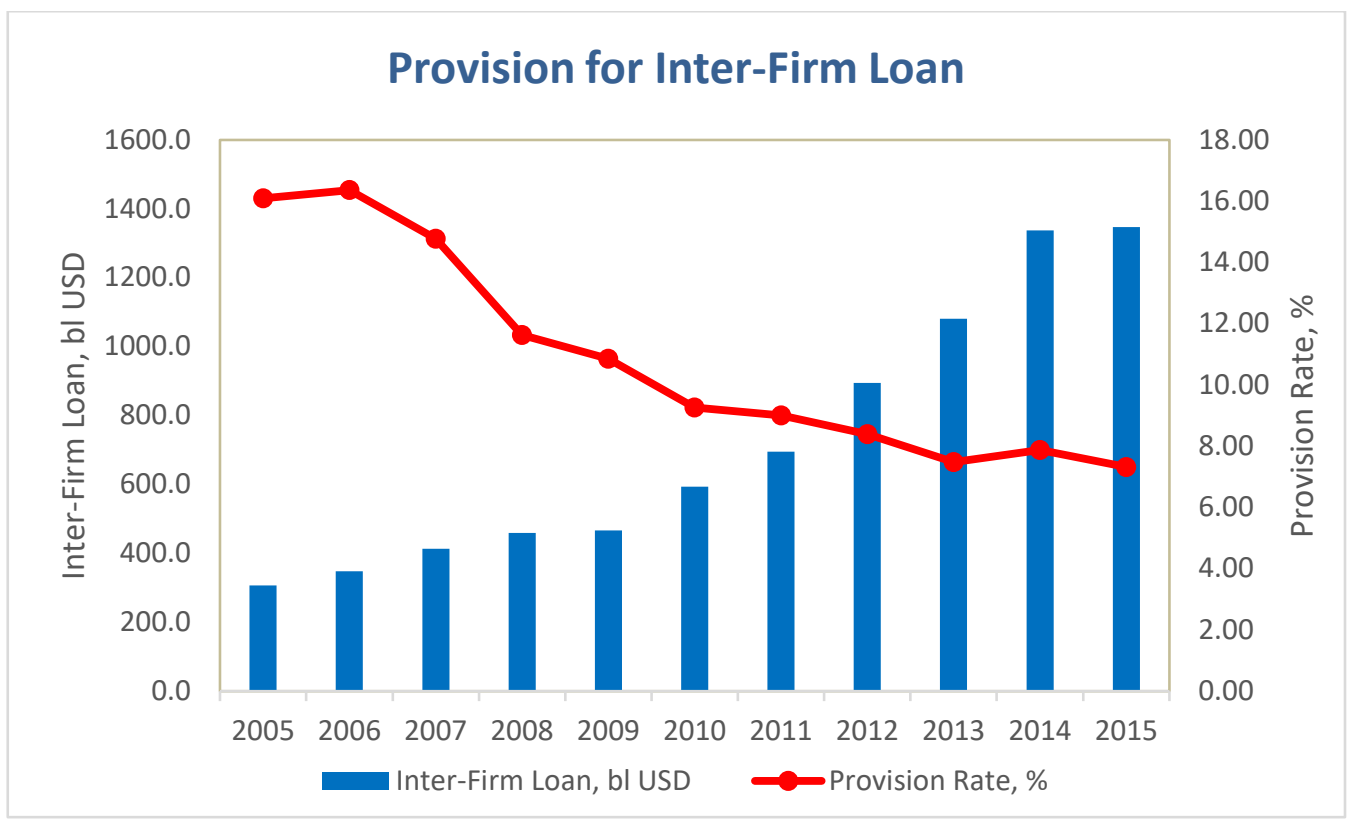




\section{Appendix}

Table A1: summary statistics

\begin{tabular}{|l|c|c|c|c|c|c|}
\hline Variable & Obs & Mean & Std. & Min & Max & Source \\
\hline USD issuer & 24,806 & 0.009 & 0.095 & 0 & 1.000 & Dealogic \\
\hline USD issuance value/revenue & 24,806 & 0.001 & 0.023 & 0 & 1.590 & Dealogic \\
\hline USD issuance outstanding/revenue & 24,806 & 0.001 & 0.014 & 0 & 0.796 & Dealogic \\
\hline Fixed asset investment/revenue & 22,618 & 0.230 & 0.488 & -0.444 & 3.519 & CSMAR \\
\hline Cash/revenue & 24,083 & 0.411 & 0.469 & 0.023 & 2.473 & CSMAR \\
\hline Inter-firm loan/revenue & 24,806 & 5.532 & 12.480 & 0.056 & 95.920 & CSMAR \\
\hline Leverage & 24,806 & 0.471 & 0.213 & 0.075 & 0.927 & CSMAR \\
\hline ROA & 24,806 & 0.696 & 0.454 & 0.089 & 2.150 & CSMAR \\
\hline Asset/revenue & 24,806 & 2.306 & 1.980 & 0.464 & 10.900 & CSMAR \\
\hline Carry trade index & 24,806 & 106.400 & 6.706 & 98.280 & 117.100 & Bloomberg \\
\hline Shadow rate & 23,367 & 15.250 & 2.377 & 10.930 & 19.220 & Wenzhou Index \\
\hline
\end{tabular}




\section{Table A2: The drivers of US dollar bond issuance (Logit)}

This table contains a set of panel Logit firm-level regressions where the dependent variable is a dummy that takes value 1 in years when a firm issues a dollar bond and the controls are the lagged values of return on assets (ROA), leverage, firm size (measured as the log of total assets), share of exports over total revenues (For. Exp.) a dummy variable that takes value 1 for firms that belong to risk sectors, the Bloomberg carry trade index (CT) and the Wenzhou shadow rate index (SR). These two indexes are not lagged. Coefficients and standard errors are multiplied by 100 to improve readability.

\begin{tabular}{|c|c|c|c|c|c|c|c|}
\hline & (1) & $(2)$ & (3) & (4) & (5) & (6) & $(7)$ \\
\hline \multirow[t]{2}{*}{$\mathrm{ROA}$} & -0.52 & -0.36 & $-0.74 * *$ & -0.43 & $-0.96 * *$ & 1.14 & -0.27 \\
\hline & $(0.34)$ & $(0.34)$ & $(0.36)$ & $(0.37)$ & $(0.40)$ & $(0.80)$ & $(0.94)$ \\
\hline \multirow[t]{2}{*}{ Leverage } & $2.47 * * *$ & $2.59 * * *$ & $2.71^{* * *}$ & $2.15^{* * *}$ & $2.67 * * *$ & 1.81 & 0.67 \\
\hline & $(0.80)$ & $(0.79)$ & $(0.82)$ & $(0.82)$ & $(0.83)$ & (1.28) & (1.36) \\
\hline \multirow{2}{*}{ Ln(Asset) } & $1.28 * * *$ & $1.29 * * *$ & $1.45 * * *$ & $1.25 * * *$ & $1.46^{* * *}$ & $0.94 * * *$ & $1.03 * * *$ \\
\hline & $(0.12)$ & $(0.12)$ & $(0.13)$ & $(0.12)$ & $(0.14)$ & $(0.34)$ & $(0.34)$ \\
\hline \multirow[t]{2}{*}{ For. Exp. } & $-1.11^{* * *}$ & $-1.15^{* * *}$ & $-1.04 * * *$ & $-1.41^{* * *}$ & $-0.98 * * *$ & -0.51 & -0.46 \\
\hline & $(0.30)$ & $(0.30)$ & $(0.31)$ & (0.38) & $(0.33)$ & $(0.70)$ & $(0.70)$ \\
\hline \multirow[t]{2}{*}{ Risky Sector } & $1.23 * * *$ & $1.23^{* * *}$ & $1.17 * * *$ & $1.13 * * *$ & $1.13^{* * *}$ & & \\
\hline & $(0.29)$ & $(0.29)$ & $(0.30)$ & $(0.32)$ & $(0.32)$ & & \\
\hline \multirow[t]{2}{*}{ CT } & & $0.09 * * *$ & & $-0.57 * *$ & & & \\
\hline & & $(0.01)$ & & $(0.27)$ & & & \\
\hline \multirow[t]{2}{*}{ SR } & & & $0.17 * * *$ & & $-1.74 * *$ & & \\
\hline & & & $(0.04)$ & & $(0.86)$ & & \\
\hline \multirow[t]{2}{*}{$\mathrm{ROA} * \mathrm{CT}$} & & & & 0.03 & & 0.06 & \\
\hline & & & & $(0.04)$ & & $(0.04)$ & \\
\hline \multirow[t]{2}{*}{ Leverage*CT } & & & & 0.13 & & 0.11 & \\
\hline & & & & $(0.09)$ & & $(0.12)$ & \\
\hline \multirow[t]{2}{*}{ Ln(Asset)*CT } & & & & $0.02 *$ & & 0.02 & \\
\hline & & & & $(0.01)$ & & $(0.02)$ & \\
\hline \multirow[t]{2}{*}{ Foreign Exposure*CT } & & & & 0.05 & & 0.06 & \\
\hline & & & & $(0.04)$ & & $(0.05)$ & \\
\hline \multirow[t]{2}{*}{ Risky*CT } & & & & 0.02 & & 0.02 & \\
\hline & & & & $(0.03)$ & & $(0.03)$ & \\
\hline \multirow[t]{2}{*}{$\mathrm{ROA} * \mathrm{SR}$} & & & & & 0.17 & & 0.19 \\
\hline & & & & & $(0.12)$ & & $(0.14)$ \\
\hline \multirow[t]{2}{*}{ Leverage*SR } & & & & & -0.23 & & -0.48 \\
\hline & & & & & $(0.29)$ & & $(0.35)$ \\
\hline \multirow[t]{2}{*}{$\operatorname{Ln}($ Asset $) * S R$} & & & & & $0.08 * *$ & & $0.10 * *$ \\
\hline & & & & & $(0.04)$ & & $(0.05)$ \\
\hline \multirow[t]{2}{*}{ Foreign Exposure*SR } & & & & & -0.10 & & -0.14 \\
\hline & & & & & $(0.11)$ & & $(0.14)$ \\
\hline \multirow[t]{2}{*}{ Risky*SR } & & & & & 0.06 & & 0.05 \\
\hline & & & & & $(0.09)$ & & $(0.12)$ \\
\hline Firm FE & $\mathrm{N}$ & $\mathrm{N}$ & $\mathrm{N}$ & $\mathrm{N}$ & $\mathrm{N}$ & $\mathrm{Y}$ & $\mathrm{Y}$ \\
\hline Year FE & $\mathrm{Y}$ & $\mathrm{N}$ & $\mathrm{N}$ & $\mathrm{N}$ & $\mathrm{N}$ & $\mathrm{Y}$ & $\mathrm{Y}$ \\
\hline Observations & 27,719 & 27,719 & 26,111 & 27,719 & 26,111 & 1,133 & 1,049 \\
\hline
\end{tabular}

Robust standard errors in parentheses, ${ }^{* * *}$ statistically significant at $1 \%,{ }^{* *}$ statistically significant at $5 \%$, and * statistically significant at $10 \%$. 


\section{Table A3: Investment in fixed assets and dollar bond issuance}

This table reports the results of a set of fixed effects regressions in which the dependent variable is capital expenditure over total assets and the explanatory variables are dollar bond issuer status (columns 1 and 2 use a dummy variable that takes value one if the firm has issued in a given year, columns and 4 use the dollar value of bond issuances over total assets, and columns 5 and 5 use the dollar value of outstanding bonds over total assets), leverage, returns on assets, firm size (log of total assets) and the interaction between the demanded value of the Bloomberg carry trade index (CT) and issuer status.

\begin{tabular}{lcccccc}
\hline & $(1)$ & $(2)$ & $(3)$ & $(4)$ & $(5)$ & $(6)$ \\
\hline Issuer & -0.06 & -0.06 & -0.85 & -0.80 & -0.97 & -1.01 \\
& $(0.04)$ & $(0.06)$ & $(0.93)$ & $(1.07)$ & $(0.87)$ & $(0.87)$ \\
Issuer*CT & & -0.00 & & 0.01 & & 0.04 \\
& & $(0.01)$ & & $(0.15)$ & & $(0.11)$ \\
Leverage & $-0.01^{* * *}$ & $-0.01^{* * *}$ & $-0.01^{* * *}$ & $-0.01^{* * *}$ & $-0.01^{* * *}$ & $-0.01^{* * *}$ \\
& $(0.00)$ & $(0.00)$ & $(0.00)$ & $(0.00)$ & $(0.00)$ & $(0.00)$ \\
ROA & $-0.03^{*}$ & $-0.03^{*}$ & $-0.03^{*}$ & $-0.03^{*}$ & $-0.03^{*}$ & $-0.03^{*}$ \\
& $(0.02)$ & $(0.02)$ & $(0.02)$ & $(0.02)$ & $(0.02)$ & $(0.02)$ \\
Size & $0.01^{* *}$ & $0.01^{* *}$ & $0.01^{* *}$ & $0.01^{* *}$ & $0.01^{* *}$ & $0.01^{* *}$ \\
& $(0.00)$ & $(0.00)$ & $(0.00)$ & $(0.00)$ & $(0.00)$ & $(0.00)$ \\
\hline Year FE & $\mathrm{Y}$ & $\mathrm{Y}$ & $\mathrm{Y}$ & $\mathrm{Y}$ & $\mathrm{Y}$ & $\mathrm{Y}$ \\
Firm FE & $\mathrm{Y}$ & $\mathrm{Y}$ & $\mathrm{Y}$ & $\mathrm{Y}$ & $\mathrm{Y}$ & $\mathrm{Y}$ \\
Observations & 25,159 & 25,159 & 25,159 & 25,159 & 25,159 & 25,159 \\
\hline Issuer is: & Dummy & Dummy & Amount & Amount & Amount & Amount \\
& & & Issuance & Issuance & Outstanding & Outstanding \\
\hline
\end{tabular}

Robust standard errors in parentheses, ${ }^{* * *}$ statistically significant at $1 \%,{ }^{* *}$ statistically significant at $5 \%$, and ${ }^{*}$ statistically significant at $10 \%$. 


\section{Table A4: Cash holdings and dollar bond issuances}

This table reports the results of a set of fixed effects regressions in which the dependent variable is liquid financial assets over total assets and the explanatory variables are dollar bond issuer status (columns 1 and 2 use a dummy variable that takes value one if the firm has issued in a given year, columns 3 and 4 use the dollar value of bond issuances over total assets, and columns 5 and 6 use the dollar value of outstanding bonds over total assets), leverage, returns on assets, firm size (log of total assets) and the interaction between the Bloomberg carry trade index (CT) and issuer status.

\begin{tabular}{lcccccc}
\hline & $(1)$ & $(2)$ & $(3)$ & $(4)$ & $(5)$ & $(6)$ \\
\hline Issuer & 0.48 & -0.31 & 19.80 & 13.00 & 17.55 & 21.23 \\
& $(1.09)$ & $(1.75)$ & $(22.80)$ & $(24.42)$ & $(20.76)$ & $(21.41)$ \\
Issuer*CT & & 0.11 & & -2.75 & & -1.83 \\
& & $(0.19)$ & & $(3.54)$ & & $(2.60)$ \\
Leverage & $-0.61^{* * *}$ & $-0.61^{* * *}$ & $-0.61^{* * *}$ & $-0.61^{* * *}$ & $-0.60^{* * *}$ & $-0.61^{* * *}$ \\
& $(0.08)$ & $(0.08)$ & $(0.08)$ & $(0.08)$ & $(0.08)$ & $(0.08)$ \\
ROA & $3.50^{* * *}$ & $3.49^{* * *}$ & $3.50^{* * *}$ & $3.50^{* * *}$ & $3.50^{* * *}$ & $3.50^{* * *}$ \\
& $(0.35)$ & $(0.35)$ & $(0.35)$ & $(0.35)$ & $(0.35)$ & $(0.35)$ \\
Size & -0.05 & -0.05 & -0.05 & -0.05 & -0.05 & -0.05 \\
& $(0.07)$ & $(0.07)$ & $(0.07)$ & $(0.07)$ & $(0.07)$ & $(0.07)$ \\
\hline Year FE & $\mathrm{Y}$ & $\mathrm{Y}$ & $\mathrm{Y}$ & $\mathrm{Y}$ & $\mathrm{Y}$ & $\mathrm{Y}$ \\
Firm FE & $\mathrm{Y}$ & $\mathrm{Y}$ & $\mathrm{Y}$ & $\mathrm{Y}$ & $\mathrm{Y}$ & $\mathrm{Y}$ \\
Observations & 25,658 & 25,658 & 25,658 & 25,658 & 25,658 & 25,658 \\
\hline Issuer is: & Dummy & Dummy & Amount & Amount & Amount & Amount \\
& & & Issuance & Issuance & Outstanding & Outstanding \\
\hline
\end{tabular}

Robust standard errors in parentheses, ${ }^{* * *}$ statistically significant at $1 \%$, ${ }^{* *}$ statistically significant at $5 \%$, and * statistically significant at $10 \%$. 


\section{Table A5: Sector classification}

SIC

Aluminum extruded products

Sector ( $0=$ non risky, $1=$ overcapacity, $2=$ =real estate, $3=$ other risky)

Aluminum rolling and drawing,

NEC

Aluminum sheet, plate, and foil

Anthracite mining

Bituminous coal and lignite--

surface

Bituminous coal--underground

Blast furnaces and steel mills

Bridge, tunnel, and elevated

highway

Cellulosic manmade fibers

Cement, hydraulic

Coal and other minerals and ores

Coal mining services

Cold finishing of steel shapes

Concrete block and brick

Concrete products

Converted paper products, NEC

Copper ores

Copper rolling and drawing

Flat glass

Glass and glazing work

Gray and ductile iron foundries

Heavy construction, NEC

Iron ores

Lead and zinc ores

Nonresidential building operators

Nonresidential construction

Organic fibers, noncellulosic

Paper mills

Petroleum and coal products, NEC

Primary aluminum

Primary copper

Ready-mixed concrete

Real estate agents and managers

Real estate investment trusts

Real property lessors, NEC

Residential construction

Ship building and repairing

Single-family housing construction

Soybean oil mills

Steel foundries, NEC

Steel pipe and tubes

Steel wire and related products

1

1

1

1

1

1

1

1

1

1

1

1

1

3

3

3

1

1

1

2

3

3

2

2

3

3

1

1

3

1

2

2

2

2

1

2

1

1

1

1

We code risky sectors using Chen, Ren, and Zha's (2016) classification of China's economic sectors into: (i) non-risky sectors; (ii) overcapacity sectors; (iii) real estate sector; and (iv) other risky sectors. ${ }^{16}$ We use information from the WIND database to code sectors that belong to the last three groups as risky. The full list is in Table A1.

${ }^{16}$ Chen, Ren, and Zha's (2016) classification is, in turn, based on the definition of the Ministry of Industry and Information Technology of the People's Republic of China which in 2014 labeled 15 industries as over-capacity industries. 
Figure A1: NFC bond issuance by currency: yield and maturity
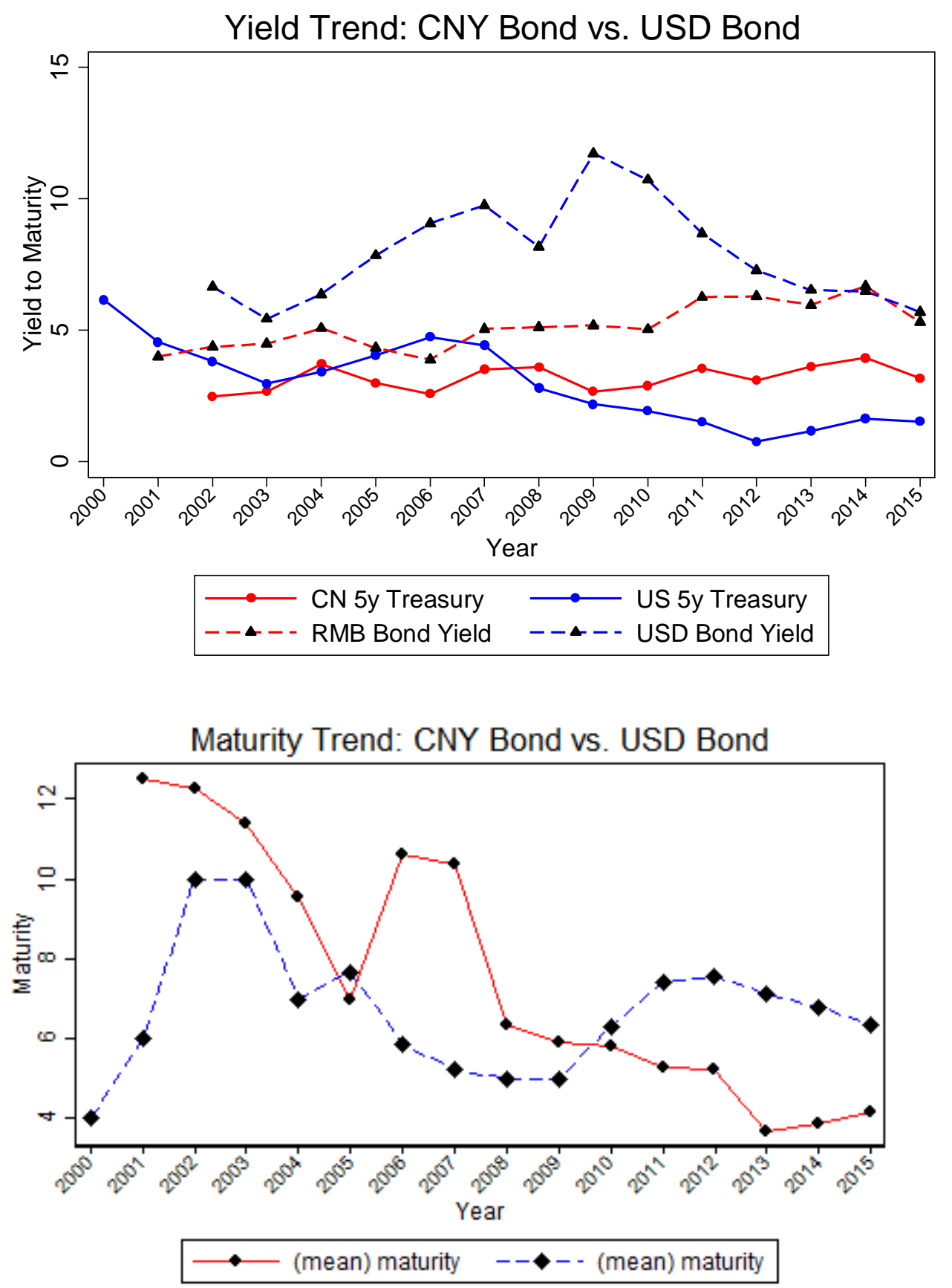

CNY: Red; USD: Blue

Data Source: Dealogic 
Figure A2: data quality

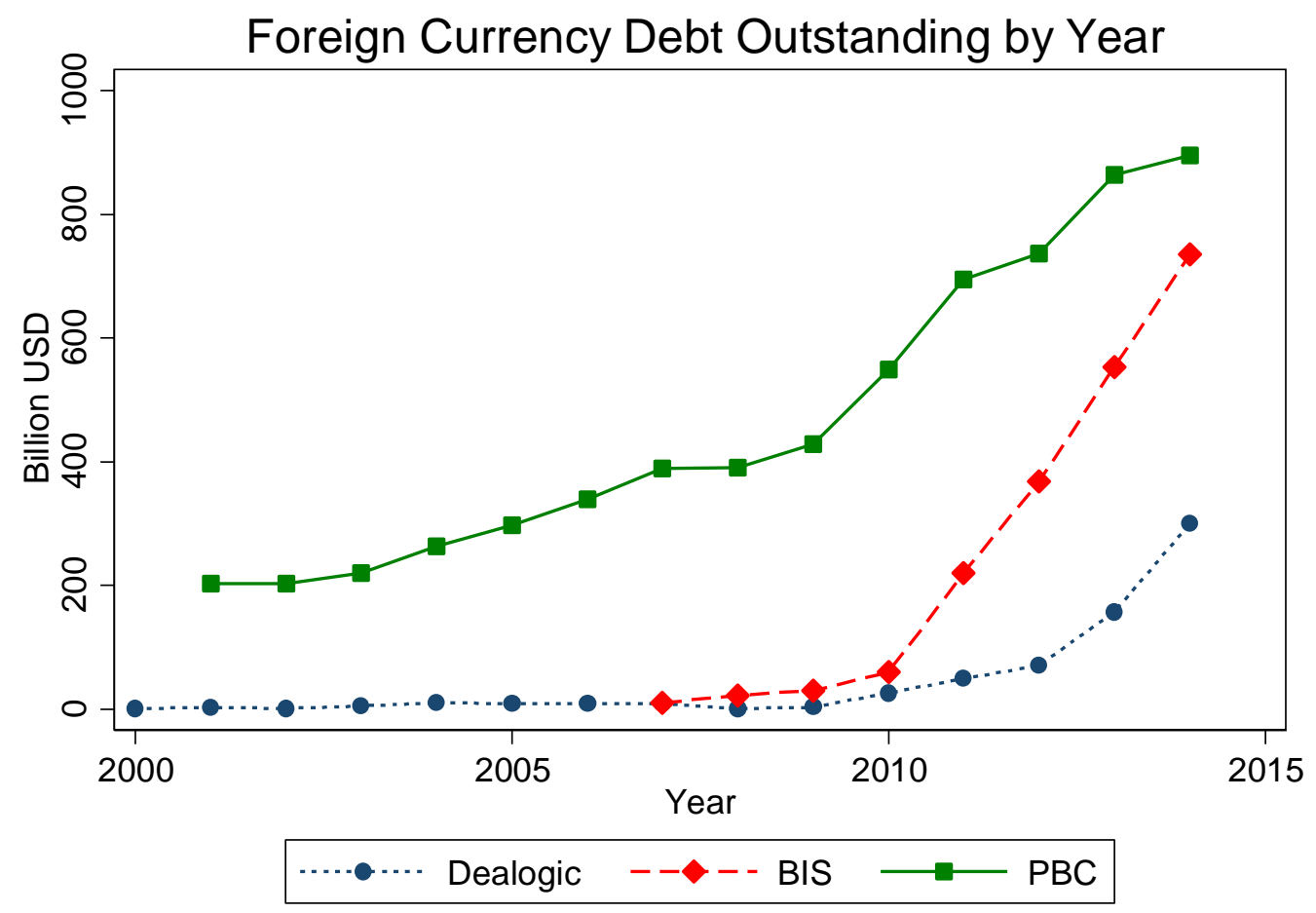


Figure A3: Intra/Inter-Group Loan Proportion

Number of Intra-/Inter-Group Loan by USD Issuer

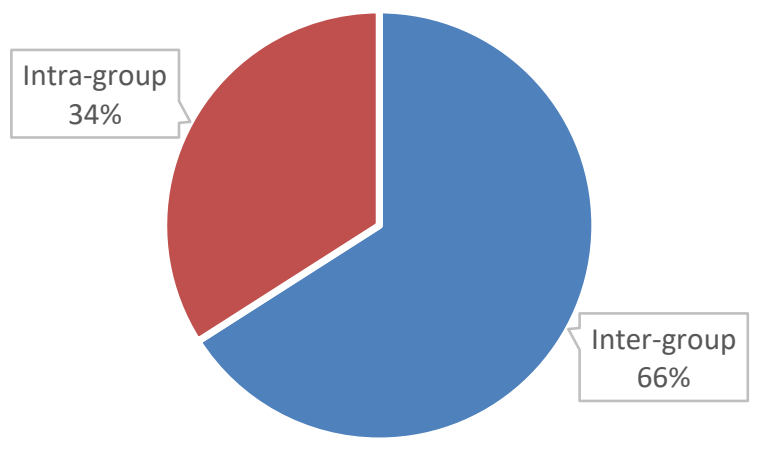

- Inter-group - Intra-group

Value of Intra-/Inter-Group Loan by USD Issuer

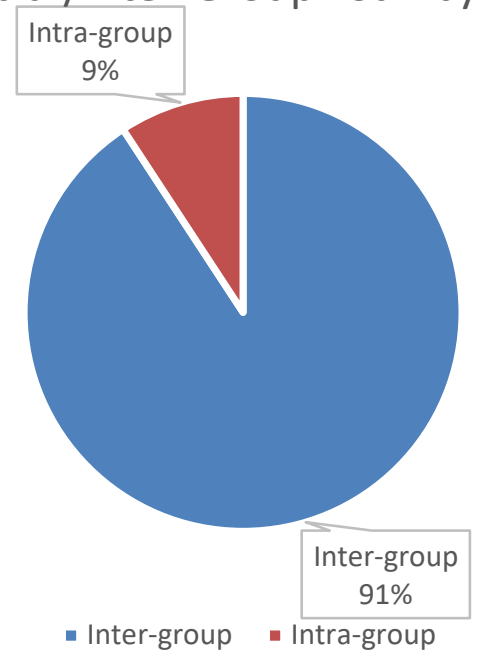

